\title{
THE WOLIO LANGUAGE
}


First edition published in 1952.

Cover: Ruins of the wall surrounding the kraton of Buton. 


\title{
VER H A N D E L I N G E N \\ VAN HET KONINKLIJK INSTITUUT VOOR TAAL-, LAND- EN VOLKENKUNDE
}

\section{1}

\author{
J.C. ANCEAUX
}

\section{THE WOLIO LANGUAGE}

\section{OUTLINE OF GRAMMATICAL DESCRIPTION AND TEXTS}

SECOND EDITION

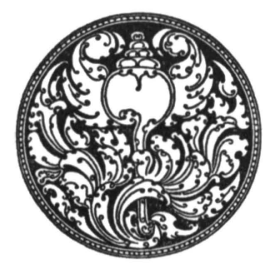

1988

FORIS PUBLICATIONS

Dordrecht-Holland / Providence-U.S.A. 
Published by:

Foris Publications Holland

P.O. Box 509

3300 AM Dordrecht

The Netherlands

Sole distributor for the U.S.A. and Canada:

Foris Publications U.S.A., Inc.

P.O. Box 5904

Providence R.I. 02903

U.S.A.

\section{ISBN 9067652326}

- 1988 Koninklijk Instituut voor Taal-, Land- en Volkenkunde, Leiden

No part of this publication may be reproduced or transmitted in any form or by any means, electronic or mechanical, including photocopy, recording, or any information storage and retrieval system, without permission from the copyright owner.

Printed in the Netherlands 


\section{CONTENTS}

PREFACE TO THE SECOND EDITION $\ldots \ldots \ldots \ldots \ldots \ldots \ldots$, vii

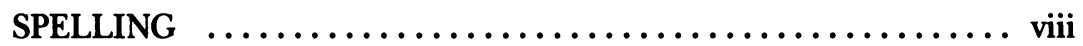

1. INTRODUCTION TO THE FIRST EDITION $\ldots \ldots \ldots \ldots \ldots 1$

1.1. The language $\ldots \ldots \ldots \ldots \ldots \ldots \ldots \ldots \ldots \ldots \ldots 1$

1. 2. Literature and writing $\ldots \ldots \ldots \ldots \ldots \ldots \ldots \ldots \ldots, 2$

1.3. The informants $\ldots \ldots \ldots \ldots \ldots \ldots \ldots \ldots \ldots, \ldots, \ldots, \ldots$

1.4. The description $\ldots \ldots \ldots \ldots \ldots \ldots \ldots \ldots \ldots \ldots 2$

1.5. The texts $\ldots \ldots \ldots \ldots \ldots \ldots \ldots \ldots \ldots . \ldots 2$

2. THE PHONEMES $\quad \ldots \ldots \ldots \ldots \ldots \ldots \ldots \ldots \ldots \ldots \ldots \ldots, 4$

2.1. Vowels $\ldots . \ldots \ldots \ldots \ldots \ldots \ldots \ldots \ldots \ldots \ldots \ldots . \ldots 4$

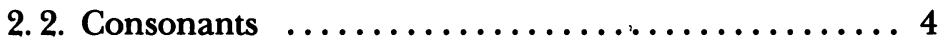

2. 3. Oppositions $\ldots \ldots \ldots \ldots \ldots \ldots \ldots \ldots \ldots \ldots \ldots, \ldots$

2. 4. Exceptions $\ldots \ldots \ldots \ldots \ldots \ldots \ldots \ldots \ldots \ldots \ldots, 8$

3. THE WORD $\quad \ldots \ldots \ldots \ldots \ldots \ldots \ldots \ldots \ldots \ldots \ldots \ldots \ldots, 9$

3.1. Word-structure $\ldots \ldots \ldots \ldots \ldots \ldots \ldots \ldots \ldots . .69$

3. 2. Word-accent $\ldots . \ldots \ldots \ldots \ldots \ldots \ldots \ldots . \ldots . \ldots 9$

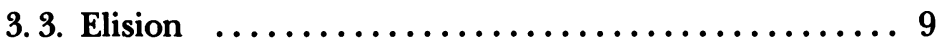

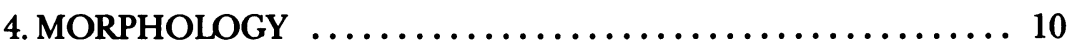

4. 0. Morphological processes $\ldots \ldots \ldots \ldots \ldots \ldots \ldots \ldots 10$

4. 1. Affixes which can be attached to words of all classes .. 13

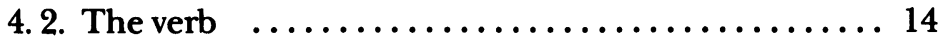

(1) Verb-stems $\ldots \ldots \ldots \ldots \ldots \ldots \ldots \ldots \ldots \ldots \ldots, 14$

(2) Declension-forms $\ldots \ldots \ldots \ldots \ldots \ldots \ldots \ldots, 25$

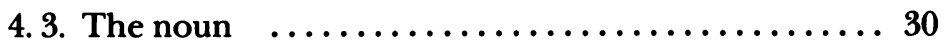

(1) Noun-stems $\ldots \ldots \ldots \ldots \ldots \ldots \ldots \ldots \ldots \ldots, 30$

(2) Declension-forms $\ldots \ldots \ldots \ldots \ldots \ldots \ldots \ldots, 33$ 
$5 . \operatorname{SYNTAX} \ldots \ldots \ldots \ldots \ldots \ldots \ldots \ldots \ldots \ldots \ldots \ldots \ldots \ldots \ldots \ldots, 35$

5. 0. Syntactical elements $\ldots \ldots \ldots \ldots \ldots \ldots \ldots \ldots \ldots . \ldots 35$

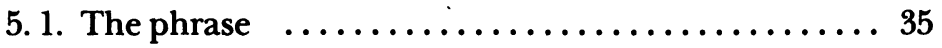

A. Substantive-phrases $\ldots \ldots \ldots \ldots \ldots \ldots \ldots \ldots, 36$

B. Preposition-phrases $\ldots \ldots \ldots \ldots \ldots \ldots \ldots \ldots, 42$

C. Verb-phrases $\ldots \ldots \ldots \ldots \ldots \ldots \ldots \ldots \ldots \ldots, 42$

D. Elements occurring in different kinds of phrases .. 46

E. Phrases containing te, ara or atawa $\ldots \ldots \ldots \ldots 49$

F. Phrases containing ne, ane, ande, ka or ko ..... 50

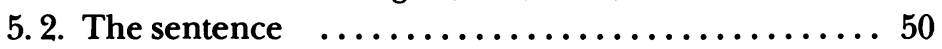

(1) Sentence-accent $\ldots \ldots \ldots \ldots \ldots \ldots \ldots \ldots \ldots, 50$

(2) Sentence-intonation $\ldots \ldots \ldots \ldots \ldots \ldots \ldots \ldots, 52$

(3) The predicate ...................... 53

(4) Phrases preceding the predicate $\ldots \ldots \ldots \ldots \ldots, 54$

(5) The subject $\ldots \ldots \ldots \ldots \ldots \ldots \ldots \ldots \ldots \ldots \ldots \ldots 5$

(6) The object $\ldots \ldots \ldots \ldots \ldots \ldots \ldots \ldots \ldots \ldots \ldots$

(7) Series of phrases showing the construction of a sentence $\ldots . \ldots \ldots \ldots \ldots \ldots \ldots \ldots \ldots . \ldots 8$

TEXTS $\ldots \ldots \ldots \ldots \ldots \ldots \ldots \ldots \ldots \ldots \ldots \ldots \ldots \ldots \ldots \ldots, 60$

ADDITIONS $\ldots \ldots \ldots \ldots \ldots \ldots \ldots \ldots \ldots \ldots \ldots \ldots \ldots, \ldots 4$

BIBLIOGRAPHY $\ldots \ldots \ldots \ldots \ldots \ldots \ldots \ldots \ldots \ldots \ldots, \ldots 7$ 


\section{PREFACE TO THE SECOND EDITION}

Thirty-five years have passed since the KITLV published the first edition of this grammar of the Wolio language. When my Wolio Dictionary (also a KITLV publication) appeared in early 1987, the grammar had been out of print for many years. Because the dictionary contains numerous crossreferences to the grammar, the fact that the latter was no longer available presented a serious problem. Fortunately, this was solved by the decision of the board of the KITLV to issue a new edition of the grammar to serve as a companion volume to the dictionary.

At the same time, a new question arose: how to incorporate into the second edition new theoretical insights that had led me to change my views on several aspects of the grammatical structure of Wolio. Incorporating these changes into the text not only would have necessitated a complete rewriting, but would also have meant that the cross-references in the dictionary would no longer refer to the proper locations in the grammar. I therefore decided to retain the original text, but to add an appendix containing the gist of my new insights, especially with regard to the morphology. These additions have been kept as brief as possible. An asterisk in the margin of the text indicates that an addition can be found in the appendix.

The spelling used in the dictionary is somewhat different from that used in the grammar. The differences between the two spelling systems are listed below. The motivation for the change in orthography can be found in the introduction to the dictionary.

A number of typographical errors have been corrected in the second edition, and a bibliography of works on Wolio language and literature has been added.

I would like to thank the KITLV for undertaking the publication of this second edition. And I wish to express my deeply felt gratitude to my wife Riet. Without her the present book would never have appeared. 


\section{SPELUING}

In my Wolio dictionary a spelling system is used based on the official modern (post-1972) spelling of Indonesian (Ejaan Yang Disempurnakan). The differences between that orthography and the one used in this book are as follows:

$\begin{array}{ll}\text { Grammar } & \text { Dictionary } \\ \text { b } & \text { bh } \\ \text { d } & \text { dh } \\ \text { s } & \text { n } \\ \tilde{\mathbf{n}} & \text { ny } \\ \text { q } & \text { ng } \\ \text { qk } & \text { ngk } \\ \text { qg } & \text { ngg }\end{array}$




\section{INTRODUCTION TO THE FIRST EDITION}

1. 1. The Wolio language is spoken on the south-west coast of the isle of Buton, south-east of Celebes, by the inhabitants of the capital Baubau, the residence of the Sultan Kota Wolio (a little landinward from Baubau), two villages south of Baubau: Meomeo and Bonebone, and five villages north of Baubau: Kadolomoko, Kadolokatapi, Waruruma, and Bungi. Besides it is spoken by the inhabitants of Tolandona, on the east coast of the isle of Muna, and the isle commonly known as Pulau Makasar (Wolio: Lizerto Makasu) ${ }^{1}$ ) lying between Muna and Buton. On the northern border of the language area there are two villages where Munanese is spoken as well as Wolio: Lowulowu (on Buton) and Baruta (on Muna).

Outside the proper territory of the language it is spoken by people belonging to the nobility ( $L a$ Ode) living scattered over the country. The total number of Wolio speakers does not surpass 25,000. As Wolio is of old the official language of the Sultanate, some knowledge of it is also found with officials of lower rank (village chiefs etc.) who do not belong to the La Ode. To this day Wolio still holds the position of official language in this region.

Wolio belongs to the Indonesian branch of Austronesian ${ }^{2}$ ). In its vocabulary it shows many borrowings from cognate languages (esp. Malay), from Arabic (often evidently with Malay as intermediary), Dutch etc.

From 1936 till 1942 the Wolio language was studied by the governmental linguist Dr. E. J. van den Berg. Alas, this scholar was killed in 1942 during the war on Celebes and all his written material was lost. The quarterly reports in which Dr. van den Berg reported progress of his researches also contain remarks on Wolio. Reading them one gets an

1) The origin of this name is discussed by E. J van den Berg in Cultureel Indië vol. I (1939), p. 366.

2) The traditional terminology and division is maintained here, because a comprehensive investigation on modern methods into the relationship of these languages is still to be done. 
impression of the great quantity of important linguistic material that was collected by him but was lost by the violence of the war.

1. 2. Wolio literature consists for the greater part of unwritten folk-tales, songs, etc. But there also exists a written literature in manuscripts. Of this literature a poem called Kanturuna mohelana (The lamp: of the sailor) is best known.

For writing Wolio, Arabic character is most used, but formerly Macassar script seems to have been used also. In recent times the modern school-education has propagated the use of Roman character. But to people having passed through such schools Roman letters are so closely connected with the Malay language that they usually write even personal correspondence in Malay. So it may be said that Wolio as a written language is falling into decay.

1. 3. The description is mainly based on the information given by La Ode Manarfa, son of the present Sultan, and supplementary information given by his wife, Wa Ode Dawia.

La Ode Manarfa spent the first five years of his life on Buton. Then he went to Macassar to go to the elementary school. He stayed there during eight years visiting his native country only during holidays. During this time he learned Dutch in the school and spoke Malay, Macassar and Buginese outside the school. Then he went to Djakarta where he visited the Secondary School (A.M.S.). There he very often spoke Dutch. When he was 21 years old he went home and stayed there during the Japanese occupation and the first time after. During that period he mainly spoke Wolio. In the beginning of 1947 he went to the Netherlands to study at the University of Leiden. His wife grew up in Buton and came to the Netherlands shortly after him. She then had some knowledge of Malay but learned Dutch only after her arrival in the Netherlands.

1. 4. The description given here is meant as an account of presentday Wolio. Questions of historical or comparative linguistics are in general left out of discussion or, in some cases, are discussed in the notes.

As this description is meant to be a contribution to linguistic knowledge rather than to linguistic theory, very few definitions are given so that linguistic terms which are generally accepted (e.g. predicate, subject, etc.) are used without explanation. Certain changes are sometimes (esp. in morphology) described in terms of processes, because this seemed to be the most practical way of description.

1. 5. The examples are preferably chosen from the texts which are 
added to the description. The material for the greater part of these texts was supplied by Mr. Manarfa. Only nrs. XII, XIII, and XV were written down at his request by a native clerk in Arabic character with an imperfect Roman transcription added. As the contents range from daily conversation to traditional tales, several differences in style may be found.

References to the texts are made in the description by a Roman cipher followed by an Arabic one, placed between brackets, e.g. (X, 5). 


\section{THE PHONEMES}

2. 0 . Since every phoneme shows variations in the way it is actualised according to different combinatory positions, the phonemes are described in the phonetical characteristics of their centre ${ }^{3}$ ). It may be said in general that one of the qualities described may be absent.

2. 1. Vowels: ${ }_{i} e^{a}{ }_{u} \quad$ All vocoids ${ }^{4}$ ).

$a$. Voiced low open central unrounded vocoid. ala - to take. baze - to bring. dala - road.

$e$. Voiced mid close front unrounded vocoid. dela - tongue. ande - if. buke - to be full.

$i$. Voiced high close front unrounded vocoid. ali - to buy. opi - to take fast hold of. andi - younger brother or sister.

o. Voiced mid close back rounded vocoid. bawo - top. alo - vapour, dew. opo - to hide oneself.

$u$. Voiced high close back rounded vocoid. buku - bone. opu - lord. bazu - pig.

2. 2. Consonants: $p \quad b \quad b \quad f \quad w r m b$

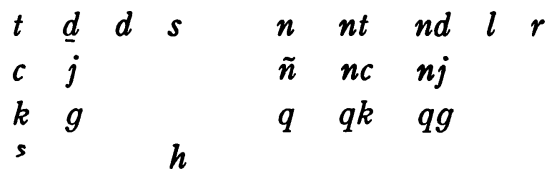

p. Voiceless bilabial stop. pada - roof. pia - how many ? lapa - to escape.

b. Voiced bilabial stop of high muscular tension. $\underline{b} e \underline{b} e$ - duck. $\underline{b} e m b a$ - to punish. koburu - graveyard.

3) That the description of the phonemes is made according to their articulatory characteristics, is not caused by aversion against the "acoustic" method but by the practical impossibility of applying it in the given circumstances.

4) The term "vocoid" (opp. "non-vocoid") is used here in the phonetical sense. In phonemics the terms "vowel" and "consonant" are used. 
b. Voiced bilabial stop of little muscular tension with simultaneous retroflexion of the tongue and lowering of the larynx. $b a d a$ - body. laba - profit. bebe - to strike.

$f$. Voiceless labiodental fricative. hurufu - letter. fajara - daybreak. masafu - forgiveness.

$w$. Voiced labiodental slightly rounded fricative. wala - side. wao - rain. mawa - flood.

$m$. Voiced bilabial nasal. mia - man. malo - night. maka - but.

$t$. Voiceless alveolar stop. tula - wart. tala - dinner-tray. tapa - end.

$\underline{d}$. Voiced alveolar stop of high muscular tension. ${ }^{d} o^{s} a$ - prayer. sahadi - Sunday. sapada - chopper.

$d$. Voiced alveolar stop of little muscular tension with simultaneous slight retroflexion of the tongue and lowering of the larynx. dodo -- to cut off. dula - tray filled with dainties. pada - to finish.

$s$. Voiceless alveolar fricative. sodo - fever. sara - council. bose - paddle.

$n$. Voiced alveolar nasal. nunu - to look for. napa - North. ana - child.

c. Voiceless prepalatal stop. cici - crack, leak. cere - kettle. baca - to read.

$j$. Voiced prepalatal stop. jamu - clock. jao - oar. jaji - in consequence.

$\tilde{n}$. Voiced prepalatal nasal. ñaza - soul. pañaki - disease. bintiñi - to offer.

$k$. Voiceless velar stop. $d u k a$ - also. kalo - necklace. kau - piece of wood.

g. Voiced velar stop. gau - to trick. gola - sugar. baga - cheek.

q. Voiced velar nasal. buqa - flower. maboqo - deaf. taqi - to cry.

s. Glottal stop. sana - six. $t a{ }^{s} i-$ faeces. ${ }^{s} a r a-$ arrack.

$h$. Voiceless glottal fricative. halo - horn-bill. hau - charcoal. baho - to bath. $m p, m b, n t, n d, n c$ (properly speaking: $\tilde{n} c$ ), $n j$ (properly speaking: $\tilde{n} j$ ), $q k$, and $q g$, though phonetically complex, form single phonemes, as they only occur in environments otherwise occupied by single segments 
only and there is no opposition between e.g. $m p$ and a cluster of another consonant with $p$ or a cluster consisting of $m$ and another consonant, as such clusters do not occur. As to their phonetical characteristics, these are easily seen from those of their constituents. It is only to be observed that in $m b$ the $b$ has characteristics similar to those of the $\underline{b}$, though it lacks the special muscular tension. Likewise $d$ in $n d$ resembles $\underline{d}$ without high tension. $m \underline{b}$ and $n \underline{d}$ do not occur.

lampa - wooden plate. mpuu - very, mere. tampa - ground.

$l a m b a$ - to rouse. bembe - goat. mbaka - reason.

ntula - to stick out. anto - contents. kanturu - lamp.

kande - to eat. ndapa - fathom. ndamu - axe.

gonco - gullet. dencu - to emigrate. qinci - tooth.

janji - to agree. talanja - naked.

buqka - lobster. maboqko - corrupt. qkaluqkalu - intestines.

miqgu - week. ruqga - to derange. jiqga - gold-coloured, orange.

l. Clear alveolar lateral.

balo - grave. lia - cave. lele - news.

$r$. Clear uvular trill with the tongue in alveolar position. saro - name. ara - or. rampa - cause.

$\underline{b}, \underline{d}$, and $f$ seem to occur in loan-words only, mainly of Arabic origin. $\underline{d}$ is in some words actualised by educated speakers as a voiced dental stop according to their Arabic models: dúnia - world; dale - the letter $\mathrm{d}$ of the Arabic alphabet. Uneducated people use $p$ instead of $f$.

sadati - custom, customary law. 'sahadi - Sunday, week.

tasubee - chaplet. habara - news.

fikiri - to think. nafasi - breath.

An initial vowel of the first word after a pause begins with a soft initial glide, the vocal cords immediately taking the position of vibration. This initial glide, that only occurs in that position, represents a zero only in the phonological system.

2. 3. The following examples show some of the oppositions of the phonemes:

$$
\begin{aligned}
& \text { dala - road, dela - tongue. } \\
& \text { ala - to take, ali - to buy. } \\
& \text { ala - to take, alo - vapour, dew. } \\
& \text { tala - dinner-tray, tula - wart. } \\
& \text { ande - if, andi - younger brother or sister. } \\
& \text { belo - ornament, balo - hole. } \\
& \text { ase - iron, aso - to sell. } \\
& \text { dela - tongue, dula - tray filled with dainties. }
\end{aligned}
$$




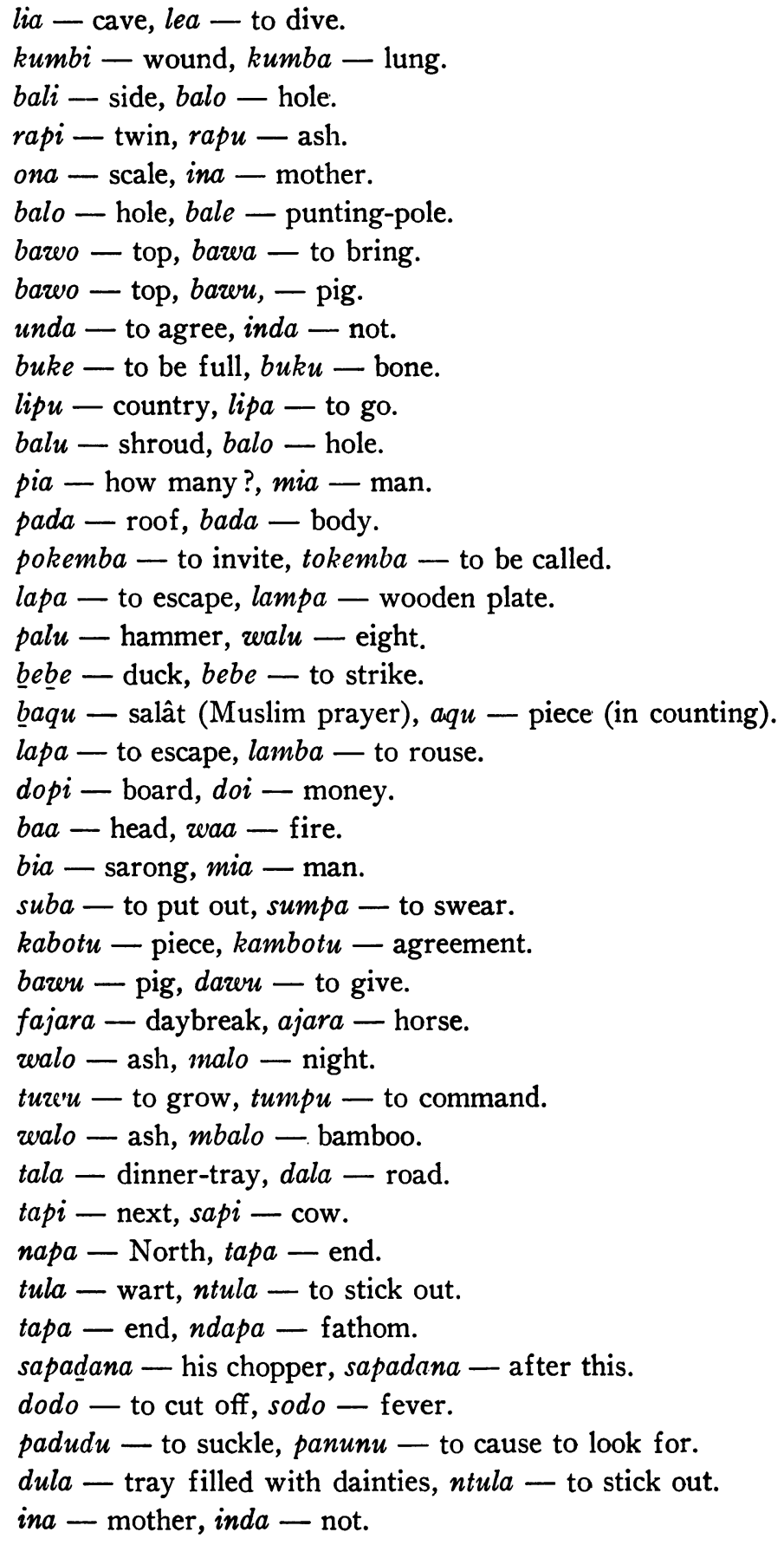




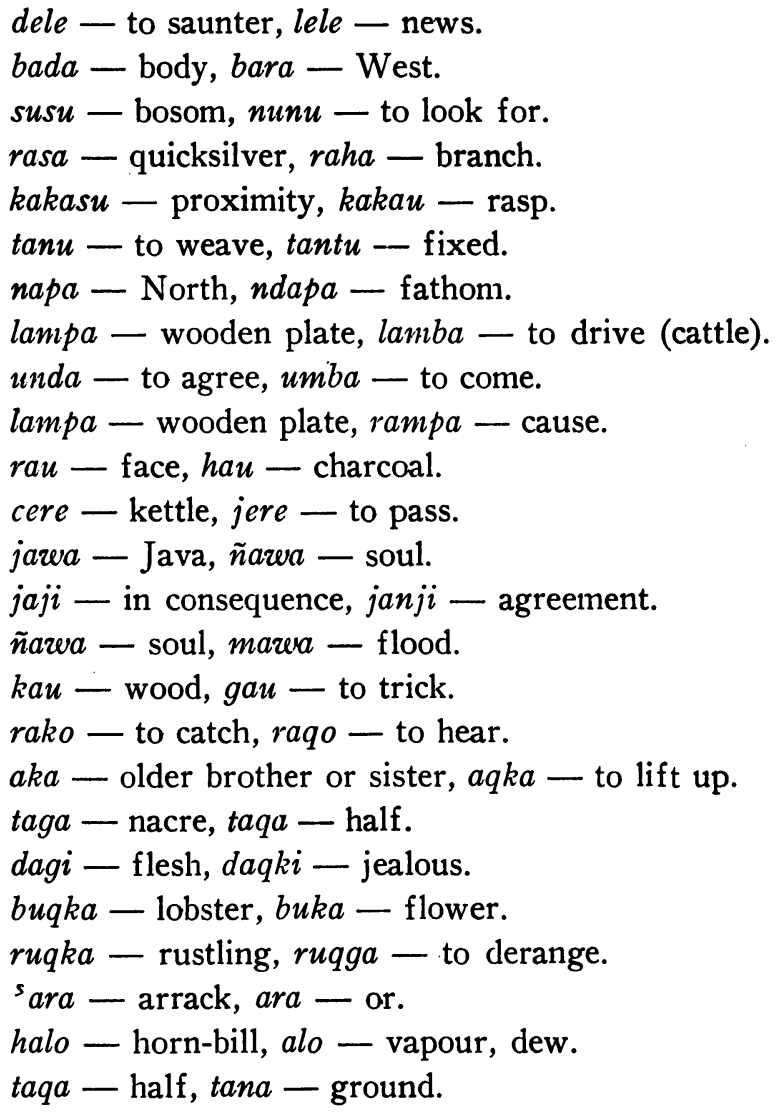

2. 4. In interjections there may occur sounds not belonging to the phonological system, viz. yeye! ( $y$ a non syllabic voiced high close front unrounded vocoid). 


\section{THE WORD}

3. 1. Every word contains one or more vowels ${ }^{5}$ ). Each vowel may be preceded by one consonant-phoneme or by none. Moreover a word always ends with a vowel. If a vowel is followed by an identical vowel and they are not separated by a consonant, they sound like one vowel of nearly double the length. If three identical vowels follow each other without a consonant separating them, the length is a little more than twice the normal length but triple length is seldom fully actualised. These "long vowels" behave in every respect in the same way as two (respectively three) different vowels and are accordingly written twice (or threefold). According to these rules the vowel-consonant-pattern of the word is: VV, CVV, VCV, CVCV, CVVV, CVCVV, CVCVCV, $\mathrm{CVVCV}, \mathrm{VCVV}, \mathrm{VCVCV}$, etc., e.g. eo, tua, uwe, pada, buea, poteo, incana, inpearo, alia, atumpu, etc. Exceptions to these rules are found in interjections, e.g. $\operatorname{sio}^{s}-$ a cry used in driving away hens.

3. 2. The word is marked by the word-accent. This word-accent consists of a high pitch of the penultimate vowel with a faint rising contour of the preceding vowels: ána, buéa, maruáa, akamekemekémo. If the penultimate and antepenultimate vowels are identical and not separated by a consonant, they both have the high pitch: akokariáámo.

Some loan-words have a different accent: 'ámala (religious contemplation), dúnia (world).

3. 3. In current, fast speech sometimes phonemes are not or scarcely pronounced. This may be the case with vowels preceding the penultimate: in wakutuuna the first $u$ is very short or is elided. With consonants preceding the antepenultimate the same may take place: mapandapanda and apebaho are sometimes pronounced mapaapanda and aebaho $\left.{ }^{6}\right)$.

5) A restriction of this rule will be discussed in the note to chapter 5. 1. (The Phrase), E, 4 (See p. 50).

B) As elision of a vowel always occurs before an accent and preferably in those cases in which the pitch is combined with intensity as usually takes place in exclamatory sentences, it may be said that the zero is a gradation of the full vowel, the shwa-gradation occurring in similar cases in other languages being passed over in Wolio. 


\section{MORPHOLOGY}

4. 0 . In this chapter the analysis of words is performed into the smallest functional units ${ }^{7}$ ). These units show a division into two groups :

1. roots which may occur as words. Elements which do not occur as words, but in the same morphological positions as roots, are called bound roots ${ }^{8}$ ).

2. affixes which do not occur as words but are always combined with roots. They always have positions in the word entirely different from those occupied by roots.

It follows that each word contains at least one root.

The morphological processes are:

I. affixation. The affixes are :

1. prefixes which are affixed at the beginning of the word before the root.

2. infi.r. Wolio has only one infix: -in-. It is discussed uncler "The Substantive", 4. 3. (1), $B, I V$.

3. suffixes which are affixed at the end of the word after the root. One word may contain several affixes simultaneously.

Some roots have a special bound form: an allomorph with a final consonant which appears before a suffix with initial vowe! (suffixes $-a,-i$ and $-a k a)$. It seems impossible to express by a rule which roots have a special bound form, or which consonant is the final one of the

7) It is clear that these functional units are the same which are called "morphemes" by L. Bloomfield (Language, 1933, repr. 1948 p. 161) and many others. These term is avoided here for two reasons :

$1^{\circ}$ In discussing a question which is important especially for Indonesian linguistics C. C. Berg lately proposed the use of the term "morpheme" in a somewhat different meaning (see: Bingkisan Budi, Leiden 1950, p. 27 sqq).

2 Taking together roots and affixes by one term ignores the fact that they are elements of different order, at any rate in many languages.

8) The term "root" is used here in the sense of "root-morpheme" or "basic morpheme" and not with the special meaning given to it by J. Gonda following R. Brandstetter (see: The comparative method as applied to Indonesian languages, Lingua, I, 1 p. 92-93). 
special bound form. Only a negative rule can be given: that final consonant is never a prenasalised one.

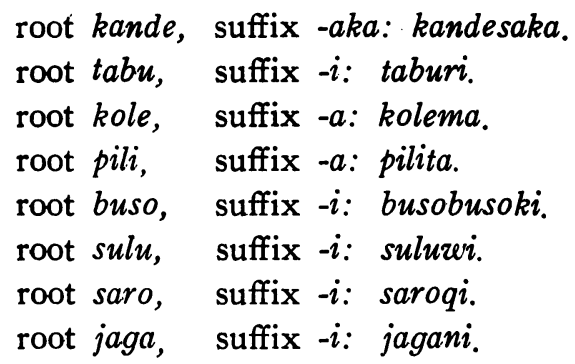

Some roots have a special bound form before one suffix but not before the other:

root $a b a, a b a k i$, but abaaka.

root taqi, taqisi, but taqiaka.

root uncura, kauncuramaka, but uncuraaka.

Some roots occur even before the same suffix in two different forms with different meanings. These two different forms may be:

$a$. a free form and a special bound form:

root rambi, rambiaka and rambitaka.

root tau, tauaka and tauraka (see: "The Verb", 4. 2. (1), B, $X I I I, c$.$) .$

b. two different special bound forms:

root gaa, gaati and gaaqi (see: "The Verb", 4. 2. (1), B, XII).

II. Reduplication. Reduplication is performed by repeating a form (word, stem or root) as far as the second vowel inclusive:

mboloqa: mbolomboloqa. kalimpopo: kalikalimpopo. baa: baabaa. If the reduplicated form is a root having only two vowels the wordaccent is also reduplicated: bátubátu, ándiándi. Apart from that the general rules of the word-accent also apply: ánáana.

The various cases of reduplication are discussed under "The Verb" (4. 2.) and "The Noun" (4. 3.). One special case of reduplication is to be mentioned here. Sometimes proper names are derived from nouns by reduplication:

hoo - heron, La Hoohoo - Heron.

kolopua - tortoise, La Kolokolopua - Tortoise.

III. Apophony. The only form of apophony in Wolio occurs only in combination with other morphological processes. It consists of repla- 
cing a stop by the corresponding nasal-stop-phoneme, e.g. $k$ by $q k$, and is therefore called prenasalisation. Prenasalisation is found:

a. in combination with certain prefixes: sa- + baa: sambaa. me- + kole: meqkole.

$b$. in compounds: two words or stems are united into one (with one word-accent!) whereas the initial stop (if there is one) of the second is replaced by the corresponding prenasalized one: penami + kuku: penamiqkuku. ulo + kobulu: Ulouloqkobulu.

IV. Composition. The principle of composition has already been mentioned under III. A distinction must be made between these "morphological" compounds having all the characteristics of one word and those compounds in which the constituents keep their own word-accent. The latter form a special type of phrase and are therefore discussed under "The Phrase" (see: the end of 5. 1. $A, 8$ ).

V. Abbreviation. Abbreviation mainly occurs with proper names in vocative. The most common type of abbreviation consists of dropping the beginning of the word whereas at least two vowels are retained, e.g. Wia for Dawia, mauma ${ }^{9}$ ) (dad) probably must be explained as an abbreviation of the reduplicated form of uma (father).

Among adult persons names are sometimes abbreviated by dropping all that follows the consonant after the first vowel: Man for Manarfa; Naf for Nafsahu.

The various forms are discussed in the following order:

1. affixes which may be attached to all classes of words,

2. the verb-forms,

3. the noun-forms.

A definition of these two word-classes (verb and noun) can not be given here. The morphological and syntactical characteristics of these (and other) word-classes will be successively discussed in the following part of the description.

Under "The Verb" and "The Noun" derived forms are discussed first. That means a discussion of the relation between root and stems. Then follow the declension-forms which may be applied to all members of the class (declension-forms in general use) or to a group of them (declension-forms of limited use) in their formal relation to the stems.

9) This is of course no proper name but it is very near to it. It is to be remarked here that in Wolio proper names are seldom used, because in many cases terms of relationship or official titles are preferred. 
4. 1. Affixes which may be attached to words of all classes are the suffixes $-m o,-p o$, and $-a k a^{1}$. Their use and meanings will be discussed under "Syntax" (see: 5. 1. D, 1.). As to their position it has to be remarked that they are always final (after roots and other suffixes), the only exception being those cases in which $-m o$ or -po are melted together with the object-suffix $3 \mathrm{~d}$ person of the transitive verb (see: 4. 2. (2), II). 


\section{THE VERB}

4. 2. (1). Verb-stems are forms which may have an actor-prefix denoting the subject of the verb-form ("action" being taken in the sense of "meaning of the verb in general"). As to their form a division can be made into: $A$. underived stems, $B$. derived stems, $C$. compound stems, $D$. phrase-stems. They may be divided into: a transitive stems. These may have an object-affix denoting the object of the verb (the object being: a complement of the verb less direct than the subject and corresponding with the object-affix of an active verb-form or the actorprefix of a passive one). $b$. intransitive verb-stems which have no object-affix.

A. Underived stems consist of roots, e.g. liqka - to go $\left.{ }^{10}\right), u m b a-$ to come, karajaa - to work.

$B$. Derived stems consist of a root and one or more affixes. A division can be made very well according to these affixes:

I. Prefix ko-. Always intransitive.

a. The immediate constituent is usually a noun:

kobulu - to be hairy, bulu - hair.

kobake - to bear fruit, bake - fruit.

kotawa - to have leaves, tarea - leaf.

kobaju - to wear a jacket, baju - jacket.

kooni - to speak, oni - voice.

This noun may be an underived one (as in the given instances) or a derived one :

kodawna - to be lucky, dawua - good luck, dawu - to give.

kokariaa - to hold a feast, kariaa - feast, riaa - to be excited ${ }^{11}$ ). or a compound:

10) All examples of verbs are given here in the form of their stems and are translated with infinitives.

11) As "derivation" is used here in the sense of a more complex formation "arising" from a simpler form (the root), the question of possible historical priority of the former (as might well be the case in this instance) remains undiscussed, as this question lies beyond the scope of a descriptive grammar. 
konamigara - to have salty taste, nami - taste, gara - salt.

b. The immediate constituent may be a bound root:

komeke - to cough, *meke, cf. kamekemeke - to cough continually.

kokete - to snigger, *kete, cf. kaketekete - to snigger continually. $k o^{5} a a$ - to produce a sound, *s $a a$, inda $a k o^{3} a a-$ [the new born child] makes no sound.

c. The immediate constituent may also be a verb: komiqku - to move, miqku - to move (transitive!).

It must be remarked that among the $k o$-stems of type $a$ there occur a number of impersonally used verbs (see "the Sentence", 5. 2. (3), 2.) denoting meteorological phenomena:

kokila - to lighten, kila - lightning.

kowao - to rain, wao - rain.

koguntu - to thunder, guntu - thunder.

koqalu - to blow (wind), qalu - wind.

koeo - the sun is shining, eo - sun.

II. a. Prefix ma-. Forms with prefix ma- are mainly intransitive. They all have a root as immediate constituent. In most cases this root is a bound one :

maluntu - to be lazy.

makasu - to be near.

magasia - to play.

makakau - to make preparations.

maqau - to burn.

In some instances the immediate constituent is a verb:

maali - to be expensive, difficult, ali - to buy.

mabaho - to be wet, baho - to bath.

manasu - to boil, nasu - to cook.

masodo - to be warm, sodo - to have fever.

maranca - to pour down (rain), ranca - to splash.

In some other instances it is a noun:

mawa - to be red-hot, wa - fire.

maati - to be shallow, ati - land, shoal.

mарири — to remain, $р и р u$ - remainder.

magaren - to be blue, garen - fog.

maijo - to be green, ijo - (the) green.

matau - to know, seems to be the only transitive ma-form.

$b$. The prefix $m a$ - coincides with substitution of $q k$ for initial $k$ of the root in the case of : maqkuru - to be lean, kuru - to shrink. 


\section{Prefix $k a$-.}

If kamata - to see (transitive), is to be derived from mata - eye, it furnishes an example of a verb-stem with prefix $k a$-. As this is the only example found, the existence of such a $k a$-stem is anything but certain.

IV. a. Prefix poma- has the meaning of "at random, on every side, without restriction and without control". Verbs with poma- may be transitive or intransitive ${ }^{12}$ ).

pomabebe - to hit out right and left, bebe - to beat.

pomasumpu - to drink without minding what one is drinking, sumpu - to drink.

pomakande - to eat at every side, kande - to eat, cf. XIII, 19 where it is said of Monkey wildly eating the bananas (the object being mentioned!).

An example of poma- with a derived stem as immediate constituent: pomapotawaiki - to smile at everybody (intrans.!), potazeaiki to smile at.

b. Poma- coincides with substitution of $q k$ for initial $k$ of the root in:

pomaqkau - to scratch one's whole body, kau - to scratch.

V. $k a--a$. The verbs having prefix $k a$ - and suffix $-a$ as mutually obligatory affixes are all intransitive and denote "a part of.... is subject to....". They all are derived from roots.

katembona - to be partly mouldered, tembo - to moulder.

(a-) kailaqa - some (of it) is gone (XV, 17), ila - to disappear kandareuna - some parts fall from (it), ndaren - to fall.

In these examples the root appears in a special bound form before the suffix (see: 4 . 0., I).

VI. Prefix me-.

Verbs with this prefix are all intransitive and denote a continuous action or state. Initials $k, c, t$, and $p$ of the immediate constituent (root or derived stem) are mostly replaced by respectively $q k, n c, n t$, and $m p$. The immediate constituent may be:

a. a verb-root:

12) In general it may be said that intransivity occurs in two cases:

10 where an object is not possible or not taken into consideration,

$2^{\circ}$ where the object is so readily understood without being mentioned or has so general a meaning that it may conveniently be omitted.

It is not easy to decide whether the intransitive poma-stems belong to the first group or to the second. 
mesumpu - to drink always, sumpu - to drink.

mempili - to be fastidious, pili - to choose.

mentaqi - to cry always, taqi - to cry.

meqkole - to sleep always, kole - to sleep.

mempeelo - to be continually looking for something, peelo -

to look for.

memate - to die continually (e.g. all the chickens of a hen), mate - to die.

$b$. a derived verb-stem:

memaeka - to be fearful, maeka - to fear.

mempotarea - to laugh continually, potaria - to laugh.

memalaqa - to be constantly high, malaqa - to be high.

c. a noun:

mendamu - to chop continually, ndamu - axe.

mencarita - to be fond of talking, carita - story.

inenjamba - to go again and again to the lavatory, jamba lavatory.

meracu - to be a poisoner, racu - poison.

Remarkable is the opposition of the two derivations of kande (to eat) : the one irregular in form but regular in meaning:

mekande - to eat continually,

and the other regular in form: meqkande, but having the special meaning of "to bite", said of fishes at angling.

VII. Prefix $t i$ -

The general meaning of this prefix seems to be "to get in the state of....". In the following examples the immediate constituents are verbal roots.

tiumba - to appear, umba - to come.

tidole - to lie down, dole - to lie.

titigi - to pour off (boiled rice), tigi - to drop.

The first and second examples are intransitive. As to the third, it is not quite certain that titigi is derived from tigi. By its transitivity and meaning titigi differs from the other $t i$-stems.

VIII. Prefix $k a$ - with reduplication of the root denotes a continual or repeated action. This form is always intransitive. The immediate constituent is always a root. This root may be:

a. a bound root occurring only in this form:

kagusagusa - to walk around with much noise.

kahaahaa - to be panting.

kasodesode - to be sobbing. 
$b$. bound roots occurring with other affixes:

kalakalaka - to be flying, polaka - to fly.

kandelendele - to be crawling around, pondele - to crawl.

kaketekete - to be sniggering, kokete - to snigger.

kailiili - to be very modest, poili - to look back.

kaboqoboqo - to be deaf-mute, to be mentally deficient, maboqo - to be deaf.

c. roots occurring as verb-stems:

kaliqkaliqka - to go by foot, liqka - to go.

kalidalida - to fidget, lida - to be restless.

kahuduhudu - to be sobbing, hudu - to hiccough.

kauncuuncura - to keep sitting, uncura - to sit.

$d$. roots occurring as nouns:

kabalebale - to stand upright, bale - stake, pole.

kandokendoke - to play at tag, ndoke - monkey.

IX. Prefix po- and prefix pe- occur in complementary distribution and in many cases have similar meaning. Properly speaking it should be necessary to give a complete list of all stems with po- or pe-. Since completeness is not pursued in this description, only some examples are given here to show their (rather divergent) meanings. Finally a few peculiarities and irregularities are discussed.

$a$. Some of these stems denote bodily states or actions, for the greater part involuntary. They all have a bound root as immediate constituent and are intransitive.

potare a - to laugh.

pomea - to yawn.

pomeke - to cough.

poqano - to swim.

pernboi - to smile.

perevilu - to spit.

b. Much more numerous are those which have a noun-root as immediate constituent. These are also intransitive.

posala - to wear trousers, sala - trousers.

pojao - to row, jao - oar.

posuo - to stay in the backhouse, suo - backhouse.

pogunturu - to fish with poison, gunturu - fish-poison ${ }^{13}$ ).

peikane - to fish, ikane - fish.

pepun - to begin, puu - stem.

13) Mal., Jav. tuba - vegetable matter, mostly an extract from the root of Derris elliptica, by which fish are stupefied. 
Transitive are:

potumpo - to cut through, tumpo - part, internode. penami - to taste, nami - taste.

c. Among those stems having a verb-stem as immediate constituent there is a great number having the meaning of plurality of the subject, whereas the object may not be found outside of the group denoted by the subject. Accordingly they are intransitive. They all have prefix $p o-; p e-$ is not found.

popeelu - to love one another.

poewaqi - to fight against each other.

pogoraaka - to call to each other.

posala - to differ from each other.

d. Other stems having a verb-stem as immediate constituent have special intransitive meaning ${ }^{14}$ ).

pebaho - to bathe, baho - to bath.

ponamisi - to suffer, namisi - to feel.

potapasi - to be washing, tapasi - to wash (things).

polimba - to remove, to pass over, limba - to go out.

posambure - to be sweeping, sambure - to sweep.

$e$. Stems with prefix $p e$ - or po-derived from a noun with prefix $k a-$ could be classified under $b$ but show some peculiarities:

1. If they are derived from $k a$-forms corresponding to $m a$-verbs (II) (see: "The Noun", 4. 3. (1), VII, c.), they are transitive and have factitive meaning.

pekarombu - to make dirty, karombu - dirtiness.

pekaqkilo - to clean, kaqkilo - cleanness.

pekandaria - to lessen, to reduce, kandaria - diminution.

pekapupu - to use up, kapupu - rest.

In this series may be included pekamate - to kill, as mate - to die, from which kamate is derived, shares many characteristics with the ma-forms.

2. The others follow the general pattern (b.):

pekabua - to angle, kabua - angling-rod.

pokatanda - to make a quid, katanda - quid.

pokataqe - to make a bundle, kataqe - a bundle.

$P e$-derivations from $k a$-forms have the same appearance as forms with prefix peka- (see below under X.) but have different meanings and distribution.

14) The two cases of intransitivity mentioned above (note 12) both appear among these po- (pe-) stems: pebaho and polimba have a meaning which does not admit of an object, the others have so general a meaning that it can be omitted. 
f. Morphological or semantic peculiarities are found in the following forms :

Substitution of a prenasalised stop for initial stop of the immediate constituent in combination with the prefix occurs in:

peqkeni - to keep hold of, keni - to seize.

pontaqa - to be halfway, taqa - middle.

peqkaadari - to study (intransitive), kaadari - instruction.

The prefix occurs twice in popotazeai - to smile at one another, potawa

- to laugh (combination of type $a$. and $c$.).

Noteworthy are the stems derivated from $k e m b a$ - to call :

pokemba - to invite,

pokembakemba - to call to each other,

pepekemba - to cause oneself to be invited.

From kawa - to come to, two po-forms are derived:

pokawaaka - to meet with, to find (transitive),

pokareakawa - to come together.

Pepepeelo, derived from peelo - to look for, has a causative meaning: to make (someone) look for.

Combination of po- with ti- (see VII.) occurs in potiqalu - to expose oneself to the wind (qalu wind). A form tiqalu does not occur but tiqalua - to be touched by air (things first hermetically packed), does occur.

X. Prefix peka-. Forms with prefix peka- are different from pe-stems derived from $k a$-forms $(\mathrm{IX}, e$.) by their meaning and by the fact that $p e k a$-forms have no corresponding $k a$-form.

pekabaqkabaqka - to go boating, baqka - boat.

pekasoo - to say "oo!", to cry.

XI. Prefix $p a$ - Stems with this prefix have a causative meaning.

The immediate constituent may be:

a. a verb-root:

pakawi - to unite in marriage, kawi - to marry.

palanto - to cause to float, lanto - to float.

papalai - to put to flight, palai - to fly.

paumba - to communicate, to say, umba - to come.

b. a derived verb-stem:

papobaju - to cause (someone) to put on a jacket, pobaju - to wear a jacket.

patiumba - to produce, tiumba - to appear.

c. a noun. Only one example is found:

pakaro - to construct, to build, karo - body. 
Some $p a$-forms show a different meaning:

pasurusuru - to force, suru - to want to share in somebody's lot. pajere - to follow, jere - to pass.

paaqka - to be open (gap), aqka - to lift up.

XII. Suffix $-i$. Stems with suffix $-i$ are all transitive. The suffix denotes a relation to the object. This relation is best described as local. The immediate constituent may be:

a. a verb-root: jagani - to protect, jaga - to take care. kompasi - to climb (a tree), kompa - to climb (intrans.). maisi - to come to, mai - to come. raqoni - to obey, raqo - to listen.

b. a noun-root:

batui - to lapidate, batu - stone. beloki - to adorn, belo - ornament. sulurei - to light, sulu - torch. saroqi - to mean, saro - name.

c. a bound root:

landaki - to tread upon, polanda - to step. mbelai - to wound, mambela - to be wounded. tadami - to sharpen, matada - to be sharp. aruki - to work loose (rice from a pot), kaaru - ladle.

$d$. a derived stem: popotareai - to smile at each other, potawa - to laugh. potawaiki - to smile at, shows the peculiarity of having the suffix twice with the consonant $k$ in between, as if the final $-i$ is attached to a root having a special bound form with $-k^{15}$ ).

Reduplication of the root is inherent to the $-i$-form in: haqahaqai - to tease, mahaqa - to be naughty. busobusoki - to gorge (food in the mouth), buso - to accumulate. From the root gaa - to part, two different $-i$-forms are derived differing in bound form of the root: gaaqi - to leave, and gaatito assort, to lay apart.

XIII. Suffix $-a k a^{2}$. Stems with suffix $-a k a^{2}$ are all transitive. The suffix denotes a relation to the object. This relation is different from

15) This seems a fine proof that the final consonant of such bound forms does not need to be a historical remainder of a former stage in which final consonants still existed. On the other hand there are cases in which a historical final consonant is retained. This appears from comparison of forms like tadami and taqisi with corresponding roots (tajam, taqis and the like) in cognate languages. 
that denoted by suffix $-i$ and very difficult to describe in a formula. The meaning of the suffix can best be seen from the examples given.

$a$. 1. When derived from an intransitive stem the $-a k a^{2}$-form implies an object:

undaaka - to approve of, unda - to agree.

gaugauaka - to tell a lie to, gaugau - to lie.

peqkaadariaka — to study (something), peqkaadari — to study (intr.).

maasiaka - to love, maasi - to feel compassion.

potareaaka - to laugh at, potazea - to laugh.

mendeusaka - to forbid, mendeu - to be unwilling.

taqiaka - to bewail, taqi - to weep.

kokariaaaka - to hold feast for, kokaria - to hold feast.

2. $-a k a^{2}$-forms derived from a bound root are also transitive:

romusaka - to collect, poromuromu - to come together.

3. Similar meanings are found with $-a k a^{2}$-forms derived from nouns.

These are also transitive:

haejatiaka - to intend, haejati - intention.

4. Somewhat different is the case of:

tumbulaka - to set in the ground (a plant), to put upside-down (someone), tumbu - to come up, to spurt up.

5. Noteworthy is the prefix $-a k a^{2}$ with a verb-stem as object denoting a simultaneous continual action, e.g.

liqkaaka rambi - to go beating (XIII, 38) ${ }^{16}$ ).

$b$. When derived from a transitive verb-stem the effect of the suffix $-a k a^{2}$ is:

1. the meaning of the $-a k a$-stem is different from that of the underlying stem:

keniaka - to seize hold of, keni - to carry, to take in one's hands.

2. the object of the -aka-stem is different from that of the underlying stem:

goraaka - to call to (somebody), gora - to exclaim.

3. The $-a k a$-stem has two objects of which one is the same as the object of the underlying stem.

pasumpuaka - to make (somebody) drink (something), pasumpu

16) That in this example the verb-stem rambi is really object of aliqkaaka, is demonstrated by the possible (though somewhat unusual) construction: $o$ rambi iliqkaakama - the beating he went with, in which rambi is characterized as a noun by $o$ and is determined by the passive participle iliqkaakana. 
- to make (somebody) drink, e.g. pasumpua! - make him drink!, pasumpuakea uzee! - make him drink water! (XV, 34).

The two objects are equivalent in their possibility of construction:

o mia sii kupasumpuakea uwe - this man, I make him drink water. o uwe sii kupasumpuakea mia - this water, I make the man drink it.

The most frequent shades of meaning are:

$A$. "for, in behalf of, intended for" etc. dikaaka - to place for, in behaif of, dika - to place.

dawuaka - to give to (somebody), dar'u - to give (something). bacaaka - to read, recite for (somebody) (VII, 2; VII, 25), baca - to read, to recite.

$B$. "with, by help of" etc. bebeaka - to hit with (XV, 21), bebe - to hit.

tudaaka - to pelt (somebody) with (something) (XI, 9), tuda to throw.

tambuniaka - to fill up with (VII, 20), tambuni - to fill up.

c. In some stems a distinction is made between two different meanings of the $-a k a^{2}$-form by using or not using a special bound form, e.g. rambitaka - to make a beating movement with (XV, 13: rambitaka karona - to beat about one's body) (type b. 1),

rambiaka - to hit with (XI, 10: rambiakea kau - to hit him with a stick) (type $b .3 . B$.$) , to beat for (V, 16: to beat (the drums) for$ (the feast contributions)) (type b. 3. A.), rambi - to strike.

tauraka - to put down (VI, 9) (type b. 1.), tauaka - to bring down for (XII, 22) (type b. 3. A.), tau - to bring down.

$d$. In case of combination of different meanings the suffix $-a k a^{2}$ is used twice:

combination of type $b .1$. with type $b .3 . B$. :

taanakaaka - to catch with (XIII, 32), taanaka - to catch, taa to stretch, to put across.

combination of type $a$. 2. with type b.3. A.:

taburakaaka - to drop for (XIII, 20), taburaka - to drop, taburi - to overwhelm.

The relation between suffix $-i$ and suffix $-a k a^{2}$ is clearly demonstrated by those roots showing both formations, e.g.

$a b a$ - to ask, $a b a k i$ - to ask (somebody), abaaka - to inquire after (something). 
taqi - to weep, taqisi - to cry over (somebody), taqiaka - to bewail (something).

taburi - to fall upon, taburaka - to drop (something).

tutuki - to pulverize, tutuaka - to pound in behalf of.

As the $-i$-stems of those roots of which no -aka-stems occur agree in meaning with the $-i$-stems of roots having both forms, and the $-a k a-$ stems of the roots having no $-i$-stems agree in meaning with the $-a k a-$ stems of the roots having both, the opposition between $-i$ - and $-a k a^{2}$ in general is clear. Besides $-i$ and $-a k a^{2}$ are not mutually exclusive. There are some $-a k a^{2}$-forms derived from $-i$-stems. From the bound root *bubu occurring in bubuaka - to cover with, is derived buburi to strew upon, and this is the base of buburiaka - to strew with.

XIV. Suffix $-a k a^{3}$. The stems with this suffix are all intransitive. The immediate constituent is either a numeral or a compound consisting of a numeral (junction-form) and a numeral coefficient (see: "The Phrase", 5. 1. A. 5.) :

siseaka - to be first, sise - one.

ruaaquaka - to be the second (thing), rua aqu - two (things).

limamiaaka - to be the fifth (man), lima mia -- five (men).

From the syntactical rules governing the use of the participles (see: "The Sentence", 5. 2. (5).) it is easily understood that especially the active participle of these stems occurs: mopatamiaakana - the fourth (man).

$\mathrm{XV}$. Reduplication. By reduplication of the roots of $m a$-stems factitive stems are formed approximating pe-stems of $k a$-nouns $(I X, e, 1$.) in meaning:

dakidaki - to ruin, madaki - to be ugly, bad.

lapelape - to put right, malape - to be right, fine, good.

romburombu - to dirty, marombu - to be dirty.

As a matter of course these reduplication-stems are all transitive.

C. Compound stems consist of two (or possibly more) roots (often with prenasalization of the initial consonant of the second, if there is one) together forming one word, e.g.

penamiqkuku - to eat little-by-little, penami - to taste, $k u k u$ periwinkle (XIII, 23).

The example given shows that penamiqkuku is transitive, a clear proof that it is an entirely new word.

D. Phrase-stems are phrases used as verb-stems without losing the characteristics of a phrase (more than one word-accent), e.g.

atalu mia - there are three of them, talu - three, mia - man. 
4. 2. (2). Declension-forms of the verb.

All formations called declension-forms of the verb are enlargements of the stems. They are characteristic for the verb.

I. Declension-forms in general use are those which are possible with all stems. They are:

a. The actor-prefixes:

$a$ - third person, aliqka - he, she, it goes, they go;

$u$ - second person, uliqka - you go;

$k u$ - first person singular, kuliqka - I go;

$t a$ - first person plural (also second person in courteous speech), taliqka - we go.

$b$. Prefix be-. The actor-prefixes have their place at the very beginning of the form. Only the prefix be-may precede the actorprefix. The meaning of this prefix is: future, intention, supposition. beaumba - it will come (VI, 1).

beakompasimea - he wanted to climb into it (XIII, 16).

beugaugauaka - you are probably telling lies (XII, 38).

c. Prefix posa-. If an action is performed by more than one person together, the prefix of the third person may be combined with a prefix posa-. This prefix has its place immediately before the stems after the actor-prefix.

aposaumba - they come together $(\mathrm{V}, 6)$.

aposapenepene - they come up together (VII, 17).

d. Prefix mo-. This prefix makes active participles and has the same place as the actor-prefixes. mo- and the actor-prefixes are mutually exclusive.

kapala mopolaka - airplane (flying ship), polaka - to fly. kapala molea - submarine (diving ship), lea - to dive.

This form may have object-affixes (see below):

mobacaakea - reciting for him (VII, 2), bacaaka - to recite for. bemokompasia - who is to climb into it (XIII, 18), kompasi - to climb into.

molazatia - receiving him (VII, 12), lawati - to receive.

In most cases $m o$ - appears in combination with suffix -na:

momatena - dead man (VII, 12), mate - to be dead.

momboorena - remaining (VII, 18), mboore - to remain.

mokoonana - scaly (XV, 94), koona - to have scales.

-na always fails to appear with mo-forms having object-affixes and in fixed combinations (like kapala mopolaka etc.). 
e. Prefix toi- combined with suffix -akana. This combination of affixes forms causative participles:

toiliqkaakana - that which causes (someone, something) to go, liqka - to go.

toimateakana - cause of death, mate - to die.

The prefix may also be $i$-:

ikobuluakana - the cause of having feathers (XII, 19), kobulu to have feathers.

f. Prefix sa-. A verb-stem with prefix sa-denotes a fact immediately preceding ${ }^{17}$ ). The actor is denoted by a "possessive" suffix (see below under "The Noun", 4. 3. (2).).

sakawamami - after we had reached (XII, 14), kawa - to come. saraqona - after she had heard (XII, 21), raqo - to hear.

samondona - when they were ready (XII, 28), mondo - to be ready.

g. Reduplication of the verbstem shows the following division:

1. Reduplication of the stem. Meaning: intensity, plurality, iteration. kupenapenamiqkukupea - I shall eat them up little-by-little (XIII, 23), stem : penamiqkuku.

abencibencimo - she tore up (XV, 29), benci - to tear.

apatipatiumba - he continuously showed (IX, 8), patiumba - to show.

amapimapii - they are ill (IV, 11), mapii - to be ill.

The meaning of plurality entails frequent combination with prefix posa-.

aposambulimbulimo - they all go home $(\mathrm{V}, 23)$, mbuli - to go home.

aposapenepenemo - they all come up (VII, 17), pene - to come up.

2. Reduplication of the root. Meaning: weakening, diminution.

mapiipii - to be slightly ill, mapii - to be ill.

malaqalaqa - to be rather tall, malaqa - to be tall.

poopooli - to be on the mending hand, pooli - to be better (a sick person).

abuntubuntulimo - he trotted (XIV, 11), abuntulimo - he ran (XIV, 9).

The following forms show irregularities in meaning:

form 2, meaning 1 :

17) The way in which $s a$-forms are used will be described later, see 5. 2. (4) b. 
amakatukatu - it broke to pieces (XV, 21), makatu - to break. form 1 , meaning 2 :

masomasodo - to be rather warm, masodo - to be hot (but more regular: masodosodo - to be a little feverish).

As a matter of course the formal distinction between 1 and 2 does not exist with root-stems.

3. Reduplication of a root may involve a special meaning so that it gets the function of a "secondary" root which implies parallel formations of both the reduplicated and the non-reduplicated root. gau - to speak, gaugau - to lie.

sumpu - to drink, sumpusumpu - to drink spirits in company ${ }^{18}$ ).

One case does not exclude the other. Besides the special meaning of "to drink spirits" (3) sumpusumpu may have the meaning "to drink continuously, to a great quantity" (1) (e.g. XIII, 40).

"II. Declension-forms of limited use:

1. Declension-forms of the transitive verb-stems.

a. The object-affixes of the transitive verbs are:

Suffixes: $-a$ third person,

$-k o$ second person singular,

-komiu second person plural,

-kami first person plural exclusive,

$-a k u$ first person singular.

Prefix : maqa- first person plural inclusive. As to this prefix, it has to be remarked that maqa- has its place immediately before the stem and after the actor-prefix: amaqapaali - he has made us buy (XIII, 43) ${ }^{18}$ ).

The suffix $-a$ has this form only with stems having $-i,-e,-o$, or $-u$ as final vowel. With stems having $-a$ as final vowel the following allomorphs appear :

$-i a: 1$. when the penultimate vowel is not $a$,

2. when the penultimate vowel is $a$ not separated from the final $a$ by a consonant.

$-e a$ : When the penultimate vowel is $a$ separated from the final $-a$ by a consonant, the final $-a$ is replaced by $-e a$. $-e a$ also occurs when suffix $-m o$ or $-p o$ is used at the same time. The $-o$ of these suffixes is replaced by $-e a$.

18) Drinking in pubs (banuana sumpusumpua) is a common pastime for men in Buton, though drunkenness in public is looked at as an infamy.

19) It must be taken into consideration that maqa- denotes the object of the causative verb. The fact that „we" is the actor of the verb "to buy" (ali) does not matter. 
taburakaakaaku - drop for me (XIII, 20), stem : taburakaaka.

aanuko - he teases you (XII, 4), stem : anu.

aabakikomiu - he asks you (XV, 75), stem : abaki.

adarerkami - he has given to us (XV, 81), stem : dareru.

amaqapaali - he makes us buy (XIII, 43), stem : paali.

beamataua - he will know it (XIV, 26), stem: matau.

apotumpoa - they cut it (XIII, 5), stem : potumpo.

ukandea - you eat it (XV, 25), stem: kande.

asaroqia - he supposes it (XIV, 44), stem : saroqi.

aparahatikaia - he takes notice of it (XIV, 40), stem : parahatika.

kupapesuaia - I make him enter (XII, 41), stem : papesua.

asikisaaia - he punishes her (XV, 23), stem : sikisaa.

kukamatea - I see them (XIV, 23), stem : kamata.

apajerenea - he followed him (XIV, 42), stem: pajere + -mo. kupenamiqkukupea - I shall eat them up little-by-little (XIII, 23), stem : penamiqkuku $+-p o$.

b. A passive participle is formed with prefix $i$ - which has the same place as the actor-prefix. The actor may be denoted by a possessive suffix (see below: 4. 3. (2), a.).

tabako itaqe - cigarette (wrapped tobacco), taqe - to wrap.

beikarajaa - that which will be done $(\mathrm{V}, 3)$, karajaa - to do, to work.

ikamatamu - seen by you, kamata - to see.

ikandena - eaten by them (I, 3), kande - to eat.

c. A passive verb-stem is formed with prefix to- which has its place immediately before the verb-stem and after the "actor-prefix". This "actor-prefix" ${ }^{20}$ ) denotes what would be the object of the active verb-stem. What would be the actor of the corresponding active stem is never mentioned. The stems with prefix to- are treated as ordinary verb-stems, so they may have the actor-prefixes and other declension-forms in general use.

atopambuli - they are sent home $(\mathrm{V}, 20)$, pambuli - to send home. atopaajo - they are attired $(\mathrm{V}, 19)$, paajo - to attire.

atobawa - they are brought $(\mathrm{V}, 19)$, bawa - to bring. motopaisilamuna - being circumcised $(\mathrm{V}, 14)$, paisilamu - to circumcise.

The distinction between the $i$ - and the moto-participle consists in the possibility of mentioning the actor with the $i$-form and the impossibility of doing so with the moto-form.

20) Placed between quotation-marks because of the difficulty of the terminology. 
Some $t o$-stems occur which do not correspond to transitive verb-stems but are derived from nouns. They denote involuntary actions.

atorampe - he was washed ashore (XII, 33), rampe - flotsam (XIII, 3).

totas $i$ - to discharge, $t a^{s} i-$ faeces.

toles $e$ - to urinate, $l e^{s} e$ - urine.

$d$. A passive potential participle is formed with prefix toi- which has the same place as the actor-prefixes have, e.g. toikarajaa - what can be made, is to be made, karajaa - to make.

2. The ma-stems and some root-stems have a special form with suffix $-a k a^{4}$ with comparative meaning:

maoge - to be great, maogeaka - to be greater.

matau - to know, matauaka - to know more, better.

mandaria - to be little, mandariaaka - to be less.

cilaka - to be unlucky, cilakaaka - to be more unlucky. 


\section{THE NOUN}

4. 3. (1). The noun may be: $A$. a root, $B$. a derivation, $C$. a compound. The compounds and the greater entities which have the syntactical functions of nouns are discussed under "Syntax".

A. Roots. Root-nouns show no peculiarities to be discussed here: ndamu - axe, kau - wood, mantorosu - sailor.

B. Derived nouns show the following classes:

I. Prefix pe-. The immediate constituent is a root-noun. Only one example is listed: pekumbi - ulcer, kumbi - wound.

II. Prefix peka-. Only one example is found. The immediate constituent is a verb-root: pekapoqko - murderer, poqko - to murder.

III. Prefix po-. The immediate constituent is a verb-stem: pototo - equilibrium, toto - to be right. poabaaka - kinsman of uncertain remove, abaaka - to ask for.

IV. Infix -in- is found in a few nouns only:

kinande - food, meal, kande - to eat.

tinauraka - heritage, tauraka - to leave behind, to put down.

As shown here the immediate constituent is a verb-stem and the infix is inserted before the first vowel of this stem.

V. Prefix pino- occurs in terms of kinship only:

pinoama - uncle, ama - father.

pinoina - aunt, ina - mother.

pinoana - nephew, niece, ana - child.

pinoopua - great-uncle, great-aunt, opua - grandfather, grandmother ${ }^{21}$ ).

VI. Prefix tope-. Some terms of kinship are derivated from numerals to which the prefix tope- is added with prenasalization of the initial consonant (if there is one).

21) Comparison with other Indonesian languages makes it probable that pinohas evolved from combination of prefix po- and infix -in- (cf. Old-Javanese: paman and penan). But from a synchronical point of view it can not be split up. 
topentalu - third cousin, talu - three.

topeapa - fourth cousin, apa - four.

Irregular is : topendua - second cousin, jua (or rua) - two.

VII. Prefix $k a$-. Most nouns with prefix $k a$ - are derived from verbstems. The best way to classify them seems to be the following:

$a$. $k a$-forms derived from root-stems:

kagagari - counting-frame, gagari - to count.

kabari - number, quantity, bari - to be many, much.

kasambure - broom, sambure - to sweep.

kataqkesi - shield, taqkesi - to ward off.

$b$. $k a$-forms derived from derived stems:

kapadola - instrument to hold out, padola - to hold out, dola to jut out.

kasuluzer - instrument to light, suluzei - to light, sulu - torch.

c. $k a$-forms corresponding with verb-stems with prefix ma- are derived from the roots of these $m a$-stems so that it may be said that $m a$ - is replaced by $k a-$. They have for the greater part the meaning of verbal substantives.

kapii - illness, mapii - to be ill.

kaputi - whiteness, maputi - to be white.

kasodo - warmth, masodo - to be warm.

kaliqu - forgetfulness, maliqu - to forget.

But other meanings also occur:

kapasa - sherd, mapasa - to be broken.

kaboqo - ear-drum, maboqo - to be deaf.

kakolo - pickles (but also: sourness), makolo - to be sour.

kapupu - remainder, mapupu - to be out, to be gone.

$d$. The immediate constituent may also be another bound root: $k a a r u$ - ladle, aruki - to work loose (rice from a pot).

$e$. A solitary instance of a $k a$-noun derived from a noun is provided by kapaso - wedge of a lathe, paso, nail, peg.

$f$. The prefix $k a$ - is combined with reduplication of the root in: kaanuanu - teasing, anu - to tease.

kainainawn - compound (of a house), inaren - garden.

$k a b a a b a a$ - wig, baa - head.

g. matuu — to be dry, to ebb, has two ka-derivations:

regular: katuu - dryness, ebb-tide, irregular: kamatuu — shell-fish. 
VIII. Suffix $-a$. Nouns derived with suffix $-a$ show approximately the same shades of meaning as those with prefix $k a$ - (see:VII, $a, b$ ). The immediate constituent may be:

a. a verb-root:

kolema - sleeping-place, kole - to sleep.

kandea - meal, kande - to eat.

saqoa - lap, saqo - to hold on one's lap.

pakea - clothes, pake - to wear, to put on.

$b$. a derived verb-stem:

pekaperaa - spittoon, pekapera - to spit out red spittle, kapera - red betel-spittle.

posuoa - locking up (of girls), posuo - to stay in the backhouse, suo - backhouse.

podazua - distribution, podaren - to distribute, daze - to give.

c. a bound root:

pikira - thought, pikiri - to think, to consider.

d. a noun:

bulua - head of hair, bulu - hair.

pasola - axle of a lathe, paso - nail, peg.

IX. Prefix $k a$ - combined with suffix $-a$. The combination of these two affixes gives no more new shades of meaning. Again the immediate constituent may be :

a. a verb-root:

kabanculeka - the opposite, reverse, bancule - to turn (round). kalaria - lathe, lari - to turn.

kapadaa - end, last phase, pada - to be ready, to be at an end. kabaria - crowd, bari - to be many, much.

b. a derived verb-stem:

kapepuиa - beginning, pepuu - to begin, puu - stem.

kapeqkenisa - banister, handle, peqkeni - to keep hold of, keni - to have in one's hand.

c. a bound root:

kararea - bed, bedroom (of a prince), marare - to sleep (a prince).

d. a noun:

kasupia - tweezers, supi - pair of tongs.

As already has been remarked and is shown by the given examples, there is no obvious contrast in meaning between the $k a$-, the $-a$-, and the $k a--a$-nouns. Only prefix $k a$ - has a peculiar trait in those $k a$-nouns which are connected with $m a$-verbs (VII, $c$.). However from some roots 
forms in two of these three groups are derived which show opposition in meaning :

darena - fortune, kadaren - present, daren - to give.

kabari - number, quantity, kabaria - crowd, bari - to be many, much.

karido - distance, karidoa - remoteness, marido - to be far away.

tootooroa - sitting, katootooroa - seat, tootooro - to sit.

$\mathrm{X}$. Suffix $-a k a^{5}$. Only one example is found of this suffix showing great resemblance in meaning with suffix $-a$ :

kandesaka - food, kande - to eat.

XI. Suffix $-i$. This suffix is found in one noun only:

buani - casting-net, bua - to pull up.

XII. Prefix pe-in combination with suffix $-i$. Only one instance is listed :

peincai - character, inca - heart.

XIII. Prefix $k a$ - combined with suffix -aka. A solitary instance of this combination showing again the resemblance of $-a k a$ with suffix $-a$ already mentioned (see under $\mathrm{X}$ ) is provided by:

kauncuramaka - seat, uncura - to sit.

XIV. Reduplication. Nouns formed with reduplication are all derived from roots. These roots may be:

a. nouns :

ana - child (offspring), anaana - child (youngster).

sara - council, sarasara - ceremonies.

kalimpopo - star, kalikalimpopo - fire-fly.

malo - night, malomalo - morning.

b. verb-roots :

lumbu - to swell, lumbulumbu - slobber, boil.

hole - to bake, holehole - sweeties.

liquliqu - maze, is derived from a bound root *liqu occurring in maliqu - to forget.

4. 3. (2). Declension-forms of the noun.

$a$. The possessive suffixes. This term, though not fully adequate, gives a sufficient indication of the meaning of these suffixes. They are:

-na for the third person: banuana - his, her, their, its house.

$-m u$ for the second person singular: banuamu - your house.

-min for the second person plural: banuamiu - your house.

$-k u$ for the first person singular: banuaku - my house. 
-ta for the first person plural inclusive (and the second person in courteous speech) : banuata - our (your) house.

-mami for the first person plural exclusive: banuamami - our house.

$b$. Prefix ko- combined with suffix -na has the meaning of an indefinite possessive: "somebody's":

kobanuana - somebody's house.

koinazenna - somebody's garden (XII, 39).

c. Some nouns have reduplication as an obligatory plural-formation, e.g. kampo - village, kampokampo - villages (II, 6).

$d$. More general is the reduplication to form diminutives:

umala - river, umaumala - brooklet.

piso - knife, pisopiso - small knife.

banua - house, banubanua - small house.

batu - stone, batubatu - small stone.

$e$. Prefix $s a-$ is the only declension-form of limited use of the noun. It occurs with those nouns which are especially used in counting and therefore are called numeral coefficients. Its meaning is: one. Further particulars are found under "The Phrase", 5. 1., $A, 5$. 


\section{SYNTAX}

5. 0 . In syntax we may distinguish two fundamental elements: the sentence and the phrase ${ }^{22}$ ). The sentence is more primary than the phrase, but for practical reasons it seems more suitable to discuss the phrase first.

\section{THE PHRASE}

5. 1. The phrase is a sequence of words marked by a special intonation consisting of a rising contour over all the words of the phrase, each word having a higher pitch than the preceding one, whereas the last word of the phrase has a special phrase-accent. This phrase-accent consists of the antepenultimate vowel having a pitch nearly as high as the penultimate vowel and sometimes still higher. This phrase-accent is of course not audible when the penultimate and antepenultimate vowels of the last word of the phrase are identical and not separated by a consonant as in such words the antepenultimate vowel always has the same high pitch as the penultimate vowel (see "The Word", 3. 2.). Besides by the phrase-accent, the phrase is marked by the fact that it is pronounced as a whole without a pause between the words whereas a short pause is normally heard between two phrases. The separate words in a phrase are marked by the word-accent only.

The beginning and the end of phrases may be marked by those words which have always an initial or final place in the phrase. These phraseinitial or phrase-final words will be mentioned below in the discussion of the various types of phrases.

A phrase may consist of one or more than one word. But, though phrases of more words are not unusual, it is remarkable that a very high percentage of the phrases in Wolio consists of one word only.

The phrases are discussed here according to six types: $A$. substantivephrases, $B$. preposition-phrases, $C$. verb-phrases, under $D$. are discuss-

22) No mention is made here of the word as a syntactical element because it always constitutes a phrase or forms part of a phrase. 
ed those elements which occur in different kinds of phrases, $E$. phrases having te, ara or atazea, $F$. phrases having $n e, k a$ or $k o$.

These types of phrases may consist of one or more than one word. Those phrases which never consist of more than one word are not discussed here.

A. Substantive phrases consist of a noun or a pronoun with or without an attribute:

$$
\begin{aligned}
& \text { bae - rice (II, 4). } \\
& \text { opea - what? (I, 3). } \\
& \text { komiu - you (XV, 27). }
\end{aligned}
$$

The attribute may be:

1. the article $o$. This article always precedes the substantive. The meaning of $o$ can not be described as definite or indefinite, its function being that of marking the following word (or words) as a separate phrase ${ }^{23}$ ).

$$
\begin{aligned}
& \text { o kariaa - the feast (V, 24). } \\
& \text { o 'Arabu - an Arab (IX, 1). } \\
& \text { o sii - this (XII and XIII, title). } \\
& \text { o iaku - I. }
\end{aligned}
$$

2. the plural-marker maqa. Maqa has its place immediately before the substantive :

maqa zertitinai - the relatives (VI, 2).

maqa incema - who (pl.) (VII, 2).

maqa anaana sii - these children (XV, 9).

When $o$ is also added it precedes maqa:

o maqa mia - the people (VII, 12).

o maqa hoo - the herons (XII, 29).

o maqa buea - the crocodiles (XIV, 44).

The use of maqa depends on whether or not the speaker wishes to express an explicit plural. It fails to appear when the plural is expressed in some other way: by numerals and the like, and with personal pronouns which have different forms for singular and plural. But the personal pronoun $3 \mathrm{~d}$ person which does not express the number may in case of being plural appear with (or without) maqa: maqa incia they.

The arbitrariness in the use of maqa is clearly demonstrated by the following example: limana te maqa aena - his arms and legs (XI, 4). When a noun has the possessive suffix $3 \mathrm{~d}$ person, maqa may be added

23) There are some exceptions which will be discussed later. 
to denote the meaning of plurality of this $3 \mathrm{~d}$ person. In that case maqa follows the noun, e.g. kapeeluna maqa - their whishes. This also occurs with a passive participle: ikandena maqa - what is eaten by them $(\mathrm{I}, 3)$.

3. a preposition with a substantive:

o daoa $i$ Baubau - the market in Baubau (II, 1). maqa mia $i$ Wolio - the people in Wolio (I, 1). boku to incia - the book for him.

As these examples show this attribute follows the substantive.

4. demonstrative words. The demonstrative words are: sii - this, these, humai or sumai, that, those, itu - that, those (at a greater distance). They are always the last word of the phrase.

o sikola humai - these schools (III, 6).

maqa mia humai - those people (II, 7).

maqa anaana sii - these children $(\mathrm{XV}, 9)$.

Sometimes sii or humai is immediately preceded by incia - he, she, it. The meaning is then "above-mentioned".

o kolo' uma incia sii - these snails (already mentioned) (X, 3).

5. a numeral (junction-form). The numeral precedes the noun. This noun is one of a special group called "numeral coefficients". The most important numeral coefficients are:

mia (man), for human beings,

( $m$ ) baa (head), for animals,

pun (stem), for trees,

boka (set), for all things having the shape of a dish or bowl, like dishes, nut-shells, etc., take (sheet), for pieces of paper, leaves, etc.

taqe (roll), for cigarettes etc.,

(m) bali
zeala (side),

giu (kind),

$\left.\begin{array}{l}\text { mpearo } \\ \text { zeruliqa }\end{array}\right\}$ (time),

taqa (half),

tumpo (internode), for sugar-cane etc.,

dodo (piece, cut or drawn off),

ide (piece),

$a q u$ (piece), for all kinds of things not belonging to the range of other numeral coefficients,

and all words denoting measures and weights or spaces of time, e.g. : 


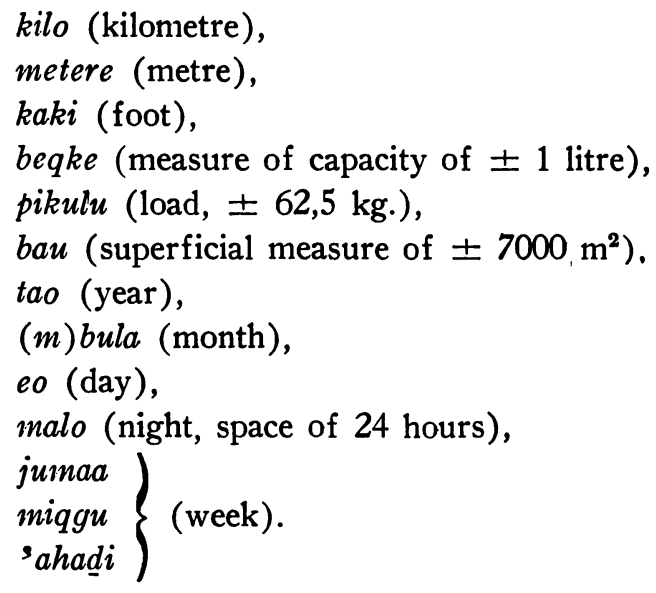

As to the form of the numerals the following is to be remarked:

A special junction-form, differing from the "independent" form which always constitutes a separated phrase and is used in counting without mentioning the thing which is counted, is only found with:

2 (independent: $j u a$, junction-form: $r u a$ ),

4 (independent : $a p a$, junction-form: pata),

6 (independent: 'ana, junction-form: nama).

The place of "one" in the series of the junction-forms of the numerals is taken by the prefix $s a$ - (see 4. 3. (2), e.) :

samia - one man ${ }^{24}$ ).

sampearo - one time.

This may be preceded by daaqia which makes it indefinite:

daaqia samia - a certain man.

daaqia saaqu wakutun - once upon a time (XIII, 1).

The interrogative numeral pia appears in the same way as the other numerals, also when it is preceded by daaqia or ara which gives it an indefinite meaning (some, a number of):

pia wuliqa - how many times? (II, 1).

ara pia malo - some nights $(\mathrm{V}, 32)$.

daaqia pia malo - a few days (XI, 22).

Ara pia also appears in indirect questions (e.g. XIII, 10).

Baa, bula, and bali always show prenasalization of the initial consonant in this construction:

24) It is to be remarked that the coefficient and counted object may be expressed by one word, as is the case in this example. 
sambali - one side.

rua mbaa - two (animals).

lima mbula - five months.

This is also often the case with take, so: satake or santake - one sheet. $P u l u$ - ten, atu - hundred, and rewu - thousand, appear as numeral coefficients :

$$
\begin{aligned}
& \text { sapulu - ten. } \\
& \text { pata atu - fourhundred. } \\
& \text { nama rewu - six thousand. }
\end{aligned}
$$

But these numeral coefficients may precede one of the series mentioned above in the same way as the numbers 2-9:

saatu tao - hundred years.

sapulu mia - ten men.

In combinations of numbers of different order the higher units precede the lower ones, so the thousands come first, then the hundreds, then the tens, and the units last:

$$
\text { saatu nama pulu saaqu - } 161 \text { (pieces). }
$$

Combination of numeral with numeral coefficient and noun in one phrase occurs only in those cases in which the number is not emphasized:

rua aqu banua - two houses.

As this seldom is the case when the number is mentioned, the normal order is that a phrase containing the noun precedes and the numeral and numeral coefficient follow in a second phrase:

loka sapuu - one banana tree (XIII, 4).

karatasi satake - one sheet of paper.

anana rua mia - their two children $(\mathrm{XV}, 1)$.

A numeral with a numeral coefficient denoting a measure may be followed by a noun denoting the kind of measure in question:

talu pulu kilo karidona - thirty kilometres in distance (II, 8).

pitu gusi kabarina - tubs seven in number (VIII, 1).

lima malo kaqeqena - five days in duration $(\mathrm{V}, 25)$.

$A q u$ is the only numeral coefficient which never appears without a numeral. All other numeral coefficients may occur in the same way as other nouns, whereas only baa, bula and bali (and, but not always, take) show the difference between prenasalized and not prenasalized form.

6. Repetition of a numeral coefficient with prefix sa- constitutes a special phrase with the meaning of "each....". saeo saeo - each day (XIII, 14). samia samia - everybody (V, 4). 
The coherence of the two words is so great that suffixes are always attached to the last one :

sagiu sagiuna - each kind of them (II, 4).

saeo saeomo - every day $(\mathrm{V}, 15)$.

7. Indefinite numerals :

maliqu - all, every,

sagala - all, all kinds of,

baribaria - all, each, one and all.

These three words precede the noun. When it receives more emphasis, baribaria may follow it, but then it is a second phrase.

maliqu hoo - all herons (XII, 24).

sagala giu - all kinds (of things) (II, 4).

baribaria loka masasa humai - all the ripe bananas (XIII, 19).

maliqu hoo baribaria - all herons together (XII, 28).

Although maliqu, sagala, and baribaria have the same place as the numerals, they do not share the characteristic of the latter of being combinable with the numeral coefficients only.

8. A second noun. A noun having a noun as attribute precedes this attribute and has the suffix -na. The attribute never has the article $o$.

o bakena loka sumai - the fruits of this banana (XIII, 24).

buluna panina - the feathers of his wings (XII, 22).

kabarina sikola $i$ Wolio - the number of the schools in Wolio (II, 4).

As shown by the examples given the attribute may have its own attribute(s). The attribute never is a personal pronoun because such a relation is sufficiently denoted by the possessive suffixes.

When the attribute is emphasized it constitutes a separate phrase:

$o$ sumuruna $o$ andi - the age of the youngest (IV, 9).

o kapepuuana o kariaa - the beginning of the feast $(\mathrm{V}, 11)$.

The suffix $-n a$ is missing when the attribute is a name of material:

banua kau - a wood built house.

pau bia - a parasol of tissue.

The suffix is also absent from the word pande in many names of professions :

pande temba - hunter, rifleman.

pande ase - smith.

Some derived nouns with suffix - $a$ may occur as attribute of a noun without the latter having suffix $-n a$ :

kariaa kawia - wedding feast $(\mathrm{V}, 5)$. 
banıa matea - house of a deceased person (lit.: house of decease) (VII, 7).

Some fixed combinations of nouns also show the absence of suffix -na. They may be considered as a kind of compounds as all suffixes are attached to the last noun, but both nouns have their own word-accent. kapulu kasumbele (na) - (his) slaughter-knife (XIII, 52).

bulu muncu(na) - (his) moustache.

The meaning of such phrases is usually a special one and in some of them an opposition exists with the normal construction with suffix -na attached to the first noun:

qinci mantoa - eye-tooth (lit.: dog-tooth).

qincina mantoa - a dog's tooth.

9. A finite verb-form. When the attribute of a noun is a finite verbform, this verb-form follows the noun and the noun usually has the suffix $-n a$ :

wakutunna aumbamo - the time that he came (XI, 22).

heqgana beaumbamo - the time that it is about to come (VI, 1).

But the suffix - na may be lacking:

haejati apakazei - the plan to arrange a marriage $(\mathrm{V}, 2)$.

10. A participle. The participle follows the noun:

mia bemogoraakea - someone who should call to him (XIII, 34).

umane mokazei - bridegroom $(\mathrm{V}, 13)$.

bazine ipakawi - bride $(\mathrm{V}, 13)$.

The participle may have its own attributes:

kambakamba itobena i dala - flowers picked along the roadside $(\mathrm{V}, 29)$.

rampe itauna mawa - flotsam carried down by the flood (XIII, 3). o mia momakidana abaca ara aburi - people who can read or write (III, 1).

11. an adjective in stem-form ${ }^{25}$ ). The adjective follows the noun:

o mia mate - the dead man (VII, 9).

bia maputi - a white cloth (VII, 10).

$o$ sadati maqeqe - the old customs (IV, 22).

12. The negation mincuana $\left.{ }^{26}\right)$. Mincuana only occurs with substantives.

25) The adjectives are a sub-class of the verbs. This sub-class consists of the verbs having prefix ma- and some root-verbs. Their most striking characteristic in distinction to the other verbs is the construction mentioned here: stemform as attribute of a noun. This does not mean that adjectives have no participles but these participles are only used as nouns : o momatena - the dead (man).

2a) The term "negation" is rather arbitrary as the meaning of mincuana is negation of the ore in distinction to another, e.g. "not X (but someone else)". 
It precedes the substantive:

mincuana iaku - not I.

mincuana gola - not sugar (XIII, 37).

13. Proper names of people belonging to the middle class may be preceded by $L a$ (for men) or $W a$ (for women). These words only occur in this position. Proper names of people belonging to the nobility may be preceded by LaOde (men) or Wa Ode (women). La Ode $(W a O d e)$ is also used as a noun, to denote people belonging to the nobility, e.g.

kaadarina maqa Wa Ode - the schooling of the Wa Ode (IV, 34). When the article $o$ is added it precedes $L a$ (or $W a$ ):

$\left.\begin{array}{l}\text { o La Musa } \\ \text { La Musa } \\ \text { o Musa } \\ \text { o La Ode X. } \\ \text { La Ode X. }\end{array}\right\}$ Lusa (Moses).
Lord X.

B. Preposition-phrases consist of a preposition and a substantive. The most important preposition is $i$ - in, on, at, to, into, etc.

$i$ kamali - to the palace (IX, 9).

$i$ umala - to a river (XI, 16).

When the substantive is one of the personal pronouns of the first person plural inclusive and exclusive, or of the second person singular and plural which appear in two forms: a longer one: iqkita, iqkami, iqkoo, and iqkomiu respectively, and a shorter one: kita, kami, koo, and komiu respectively, the shorter form is preferred after $i$ :

$i$ kita - with us.

The substantive preceded by a preposition may have its own attributes:

$i$ maqa kampokampo - in the villages (II, 6).

$i$ inazuna Clouloqkobulu - in the garden of Hairy-Caterpillar (XII, 33).

But the substantive preceded by a preposition never has the article $o$. A preposition-phrase is never attribute of a substantive as a substantive together with a preposition and its substantive is contained in one phrase (see "The Substantive-phrase", 3.). The negation of a prepositionphrase is inda:

inda $i$ banuana - not in his house.

C. A verb-phrase consists of a finite verb-form with or without attributes.

abawamea - she brought him (XII, 22). 
kumagari - I am cold (XII, 37).

atobemba - they are punished (IV, 19).

The attribute may be:

1. inda and boli (not). These two words never occur with substantives (as these have mincuana as negation).

Inda precedes the verb. It is the negation of a statement. inda bekuponamisi - I would not suffer $(\mathrm{XV}, 25)$.

inda abari - they are not many (III, 2).

inda atotauraka - they are not laid down (VI, 9).

Boli is the negation of a command or a request. It precedes the verbform which usually is an imperative.

boli alaakea - do not take them $(\mathrm{XV}, 11)$.

bolimo ${ }^{27}$ ) sapo - do not come down $(\mathrm{XV}, 96)$.

bolimo ose - do not follow (XV, 69).

But sometimes, in a polite request, the second person of the verb follows boli:

boli usabu - please do not jump down (XIII, 28).

2. maqa. Maqa denotes an explicit plural of the subject. Its place is at the very end of the phrase.

akaliqkaliqka maqa - they go by foot (II, 10).

inda amaqule maqa? - do they not get tired? (II, 12).

apeelomo ikane maqa - they looked for fish (XII, 6).

anunumo kabencina biana inana sumai maqa - they looked for the torn pieces of their mother's sarong (XV, 43).

3. an adverb. Some adverbs always precede the verb, though not necessarily immediately, e.g.

sadia - always,

pada - already,

daaqia - now, it is the case that.... ${ }^{28}$ ),

so - only, just,

coba - just (with an imperative).

sadia amahaqa - they are always naughty (IV, 16).

padamo uka kudikaia - I have already put it again (IX, 10).

daaqia amakidikidi - he was small (XII, 2).

daaqia akeniaka mpun - they held very fast (IV, 22).

27) The suffix tmo will discussed later.

28) This adverb must be distinguished from the verb daaqia - there is, are. daaqia pata mia - there are four (IV, 2).

daaqia opuamami - there was an ancestor of ours (VIII, 1).

This verb daaqia often occurs with a te-phrase (see below). 
so aligkamo - he just ran (XIV, 10).

so apancuru. - he just went on (XII, 47).

coba kamatea - just look at it (XV, 71).

These adverbs also precede inda:

sadia inda araqoni - they are never obedient (IV, 17).

Other adverbs always follow the verb, e.g. mpun - very, dadi - if you dare (with imperative).

aposalamo mpuи - he differed greatly (XI, 3).

akeniaka mpun - they held very fast (IV, 22).

papesua dadi! - put in if you dare! (XII, 42).

4. an object. As a matter of course an object only appears with transitive verbs.

apokazeaaka kaadari - they are taught (IV, 24).

apeelomo ikane maqa - they looked for fish (XII, 6).

As these instances show the object follows the verb. The only exception is opea - what?, which precedes the verb when forming part of the same phrase:

opea apeqkaadariaka? - what do they study? (IV, 29).

A personal pronoun never appears as object within the same phrase as the verb. It is replaced by an object-affix:

beabawea - he would take him (XI, 21).

apaumbamea - she said to them (XV, 74).

aalamea - they took it (XV, 54).

If the verb allows two objects, one of them is denoted by an objectaffix, the other follows the verb:

adarenmea pasali - they give them a festive gift $(\mathrm{V}, 21)$.

atudaakamea batu - he threw stones at him (XI, 9).

The object may have its own attributes which are incorporated in the verb-phrase :

anunumo kabencina biana inana sumai maqa - they looked for the torn pieces of their mother's sarong $(\mathrm{XV}, 43)$.

temo aala parewana tanuana inana La Mbatambata - and he took the weaving-loom of $\mathrm{La}$ Mbatambata's mother (XV, 21).

5. another finite verb-form. When a finite verb-form appears as attribute of another finite verb-form, the latter precedes and they both have the same actor-prefix.

amendeu asapo - he refused to go down (XII, 2).

apeelu beamataua - he wants to know it (XIV, 26).

mai sapo! - do come down! (XII, 45).

The attribute may have its own attributes: 
apeelu sadia akande? - do they always want to eat? (IV, 13).

amembali asapo $i$ tana - they may go down to the ground (IV, 24). abari amboorcaka $i$ banua - they usually live at home (IV, 32).

It must be remarked that attributes of a verb which are separated phrases when the verb is predicate (e.g. a preposition-phrase) become one phrase together with the verb when this verb is attribute of another verb. This makes clear which of the verb-forms is attribute to the other. Attention will be drawn to the same phenomenon with all verbs which are not predicate (see below under "The Sentence").

When the verb and the attribute are both transitive they both may have an object-affix. These two object-affixes denote the same object:

apadea aalea - he finished it taking it away, i.e.: he took it all (XII, 20).

apadea akandea - he finished them eating them, i.e.: he ate them all up (XIII, 22).

The passive participle-construction corresponding with such a phrase with two object-affixes shows two participles:

maqa rindi ipadana uka ikenina maqa mia - walls which people had touched already (VIII, 4).

This construction corresponds with the phrase : apadea uka akenia maqa - they finished them touching them.

6. A participle, whether as attribute of a noun or used as a substantive, may have all attributes of the finite verb. Besides it may have the construction of a noun with a noun as attribute (cf. Substantivephrases, 8.).

mokenina kapooli - the one who held power (XIII, 6). sadia ikandena maqa - what is usually eaten by them (I, 3). iasona maqa mia - what is sold by the people (II, 3).

In the same way as the verb which is attribute (see above: 5.), a participle may have attributes within the phrase which are always separate phrases with a finite verb-form which is predicate:

ikandena maqa i nuncana talu mpearo humai - what is eaten by them in these three times (I, 4).

o mia momakidana abaca ara aburi - people who can read or write (III, 1).

o maqa mia molarvatia $i$ kabaloqko humai - the people who receive him in the grave (VII, 12).

It must be remarked that the negation of the participle even when it is used as a substantive always is inda: 
inda ikobuluakana panina sumai - what made that he had no wing-feathers anymore (XII, 19).

7. Verb-forms with prefix sa- may have the same attributes within the same phrase as the finite verb-forms have. Among these attributes there also occur those which are separate phrases with a finite verb-form which is predicate:

sakamatana La Ndokendoke - when he had seen Monkey (XII, 35).

sakawamami i tawo - when we had reached the sea (XII, 14).

sakamatana hunai - when he had seen that (IX, 18).

An attribute consisting of a preposition with a substantive may also occur as a separate phrase, as is the case in the following example where the attribute $i$ banuana follows the phrase containing the subject of the $s a$-form. This subject always constitutes a separate phrase (see below under "The Sentence").

sakazwana o La Ndokendoke i banuana - after Monkey had come home (XII, 13).

$D$. Among those elements which occur in different kinds of phrases we may distinguish:

1. the suffixes $-m o,-p o$, and $-a k a^{1}$,

2. some words of which $u k a$ is the most important.

1. The suffixes $-m o,-p o$ and $-a k a^{1}$ are only formally part of the word to which they are attached. Semantically they belong to the whole phrase in which they appear. They are usually attached to the first word of the phrase.

mopakaronamo galampa - those who build the galampa (V, 7).

podomo momarampina $i$ momatena humai - all close relatives of the dead man only (VII, 12).

indapo mokoonana - not yet scaly (XV, 94).

aumbaaka $i$ koburu - when arrived at the graveyard (VII, 9).

But some words never have one of these suffixes. The most important are: the article $o$, the prepositions $i$ and $t o$, and $n e-$ if, when ${ }^{29}$ ). If one of them is the first word of a phrase containing -mo, $-p o$, or $-a k a^{1}$, the second word of the phrase has the suffix ${ }^{30}$ ):

29) These words (and some other) which have only one vowel and usually occur at the beginning of a phrase, show some peculiarities which will be discussed later.

30) In this case the word accent is taken as criterion for the word. This way of analysis is supported by the fact that there are other examples of -mo occurring with a word that is not the first of a phrase. 
i apaimo? - where? (XII, 36).

o sarosaromo uka - a custom (VI, 7).

ne akareamo - when it comes (VI, 1).

The word so - only, just, does not have the suffix when it is followed by a verb-form:

so aliqkamo - he just ran (XIV, 10).

so abukemo - it was full (XV, 35).

so umboombooremo itu - you just stay here $(\mathrm{XV}, 27)$.

But when followed by a substantive it may have it:

somo susuna - only her breasts (XV, 94).

The suffix $-a k a^{1}$ marks the phrase in which it appears as an attribute of the predicate. This phrase may precede the predicate; then its meaning is temporal. When it follows the predicate, its meaning is final.

amambotuaka - when a decision has been reached (VII, 3).

abukeaka - when it is full (VII, 21).

indaaka amaisia Kabinduboroko - that it may not be visited by a "Pull-throat" (VI, 11).

As shown by these examples the nucleus of a phrase containing $-a k a^{1}$ usually is a verb-form. But this not necessary. It may also be a preposition-phrase.

$i$ banuaaka - when (he is) in the house.

All attributes of the verb-form are part of the same phrase, also those which are separate phrases in case of a verb-form being a predicate:

karwaka wakutuuna - when the time has come ${ }^{31}$ ) (VII, 6).

aumbaaka $i$ koburu - when arrived at the graveyard (VII, 9).

abariaka mia i daoa - when there were many people at the market (IX, 2).

The suffixes -mo and -po denote some emphasis on the phrase. Accordingly they usually occur as a part of the predicate of a sentence. As - mo has a meaning of greater definiteness it often denotes sure, ascertained facts and accordingly it often has the meaning "already", whereas - $p o$ usually denotes uncertain, future things. An imperative with - $p o$ means a request; an imperative with - $m o$ denotes a stringent command. Combination with inda - not, gives rise to indamo - no more, and indapo - not yet.

saopeamo? - how many? (IV, 9).

akambelimbelimo - he was walking (XIV, 1).

31) This example shows that when the subject is part of the same phrase, the actor-prefix of the $3 \mathrm{~d}$ person of the verb may be absent. 
bekumembalimo ikane - I shall certainly become a fish (XV, 70). bolimo ose! - do not follow! (XV, 69).

mbulimo! - do go home! (XV, 70).

maipo! - just come here!

taburakaakaakupo - drop for me! (XIII, 20).

o eopo sii - only to-day, not until to-day.

indapo mokoonana - not yet scaly (XV, 94).

pia - how many?, appears in some fixed combinations with -mo: $i$ piamo? - when? (in the past, opp. : naipia? - when?, in the future); $i$ piamo itu - formerly, in olden times.

2. $u k a$ or $d u k a$ which often has the meaning "also, again" (but more often is hard to translate) is usually the second word of a phrase: amapupumo uka - they are also finished $(\mathrm{V}, 35)$.

himbomo uka humai - the same (also like that) (I, 7). wakutuuna uka humai - the same time $(\mathrm{V}, 10)$.

But in a phrase beginning with one of the words which never have one of the suffixes $-m o,-p o$, or $-a k a^{1}$ (see above onder 1.), $u k a$ (or $d u k a$ ) is the third word:

i apaimo duka? - where? (XII, 36).

ne aumba uka sampearona - when he came back next time (XI, 21).

o ndokemo duka mohobutina buluna panina La Hoohoo sumai the same monkey that pulled out Heron's wing-feathers (XII, 32). With a substantive-phrase of type 8 (a noun having a noun as attribute) $u k a$ follows the attribute, so it moves one place further back: incana humai $u k a$ - in the meantime (IX, 4).

There seems to be no fixed rule for the use of the allomorph $d u k a$ for $u k a$. Only with temo there seems to be a constant preference for duka: temo duka - and also (XV, 26, 61, and 65).

In some cases the use of $u k a$ involves a special meaning:

sadia $u k a$ - still, sadia - always.

samiamiana uka - a unique man (VIII, 2), samiamiana - alone, single.

Podo which also occurs in alle kinds of phrases has the meaning "evidently, only". It is always phrase-initial and accordingly the phrasemarker of substantive-phrases $o$ is absent after podo:

podomo kajaganina Seetani - only protections against demons (VI, 13).

podomo momarampina i momatena humai - close relatives of the dead man only (VII, 12). 
podo beuganganaka - you are probably only telling lies (XII, 38). E. Phrases having te - and, with, ara - or, or atawa - or, as nucleus need a special discussion as they show some peculiarities in their syntactical use which distinguish them from other phrases.

1. When the attribute is a substantive the te-, ara-, or atawea-phrase is distinguished from a preposition-phrase by the fact that it is a separate phrase even when it is the attribute of a substantive: biana te bajuna - her sarong and her jacket $(\mathrm{XV}, 28)$.

Wa Turuqkoleo te La Mbatambata - Wa Turuqkoleo and La Mbatambata (XV, 60).

A phrase with $t e, a r a$, or atarea is the normal termination after a series of co-ordinate substantive-phrases:

apeqkaadariaka baca, buri, tanu, posorumba, pesulasula te sámala - they learn reading, writing, weaving, sewing, embroidery, and contemplation (IV, 35).

o tandakia, posusua atarea posuoa - circumcision, earpiercing, or locking up $(\mathrm{V}, 5)$.

$T e$, ara, and atawa are usually phrase-initial and accordingly $o$ is absent from the following substantive.

The negation of a $t e$-phrase having a substantive as attribute is inda, e.g. indamo te buluna panina - not having any more wing-feathers (XII, 18).

Noteworthy is the use of such a te-phrase as attribute of the impersonal verb-form daaqia - there is, are.

daaqia te haejati apakawi - there is a plan to arrange a marriage $(\mathrm{V}, 2)$.

daaqia te anata? - have you any children? (IV, 1).

daaqiapo te eo - the sun was still there (IX, 5).

2. In distinction to a preposition te may have a finite verb-form as attribute. This verb-form may have its own attributes within the same phrase but also as separate phrases so that it looks like a "subordinated clause".

te apetandoa $i$ siqkaru - and a ring is used to lay it on (VI, 6). Ara- or atazea-phrases having a finite verb-form seldom occur.

3. The attribute may also be a preposition with a substantive, but this seems to be the case only when a preposition-phrase precedes:

$i$ umane mokari ara $i$ bareine ipakarei humai - at the bridegroom's or at the bride's $(\mathrm{V}, 13)$.

4. te also occurs without an attribute or with $d u k a$ only. In this case it always has the suffix $-m o$ : 
temo duka - and also (XV, 26, 61, and 65),

or it is replaced by its allomorph tee ${ }^{32}$ ) (e.g. XI, 13; XIII, 33; $\mathrm{XV}, 45)$.

$F$. The last types of phrases to be discussed here are those containing $n e$, ande, ane - if, when, $k a$ - then, for, or $k o$ - and.

1. The attribute of ne (ane or ande) usually is a finite verb-form with its attributes. But it may also be another word or combination of words which may be predicate of a sentence. It may be said that the attribute shows the same construction as a sentence (see the following chapter) but in its entirety it constitutes one phrase even when it contains elements which otherwise constitute separate phrases. This phrase always precedes the predicate of the sentence ne akawamo wakutuuna - when the time has come $(\mathrm{V}, 9)$.

ne aumba uka sampearona - when he came back next time (XI, 21).

ande inda ukandea ntaupo o kawolena amamu - if you had not eaten your father's cleaned fish $(\mathrm{XV}, 25)$.

It is remarkable that a $n \ell$-phrase may have a demonstrative word as attribute :

ne pada apebaho humai - when he had bathed (VIII, 4).

2. $K a$ introduces a finite verb-form or a construction resembling a sentence. This verb-form or sentence-like construction denotes something which follows or which is the reason of that denoted by the predicate of the sentence. When $k a$ is followed by such a sentence-like construction, this construction shows the same composition of phrases as the corresponding sentence. $K a$ is the first word of the first phrase of this construction which always comes after the predicate of the sentence with its attributes.

32) It is remarkable that all the words which have only one vowel: the article $o$, the prepositions $i$ and to, te (and), so (only), ko (and), $k a$ (for, then), ne (if when), $L a$ which precedes proper names of men, and $W a$ which precedes proper names of women, usually appear as the first word of a phrase. They may occur in the middle of a phrase (except $k o, k a$, and $n e$ ), when two of them are combined (but not all combinations are really used!) or in those phrases which contain elements usually occurring as separate phrases. But in these forms they never are the last word of the phrase and they never constitute a phrase of themselves. In those cases they are represented by a form having two (identical) vowels instead of one, or have the suffix -mo, e.g. temo (see above). tee occurs regulary and so does soo. But the two-vowel-forms of the other especially occur as nouns with the meaning of self-denotation: $o o$ - the word " $o$ ", $o$ kaa the word " $k a$ ". So it is clear that words having only one vowel may occur only at the beginning or in the middle of a phrase, but never as the last or the only word of a phrase. 
ka indapo ainbuli - for he had not yet returned (XII, 13).

$k a$ alagu $d u k a$ - then again she sang $(\mathrm{XV}, 85)$.

ka sakareamami $i$ tawo o La Hoohoo aliqkamo duka samiamiana

- for when we had reached the sea Heron walked off alone (XII, 14).

3. Phrases with ko always appear at the beginning of a sentence which usually is interrogative. They denote a new theme to which the discourse passes over in coherence with the preceding. Ko always is the first word and its attribute is a substantive with its attributes.

ko maqa bawine - and the girls (are they taught the same?) (IV, 31).

ko iqkoo - and you (how many leaves?) (XIII, 12).

ko ikanemiu itu - and these fish of yours (where did you get them?) (XV, 80).

THE SENTENCE

5. 2. The sentence is the maximal linguistic unit of utterance ${ }^{33}$ ). It may consist of one or more phrases. The sentence is marked by the sentence-accent and, when it consists of more than one phrase, by the sentence-intonation.

5. 2. (1). The sentence-accent always occurs on the last vowel of the sentence and has four types:

1. Low pitch-accent: the pitch of the last vowel is as low as the pitch of the first vowel of the sentence. This type of accent is characteristic for statement-sentences (symbol: .).

apoilimo $i$ talikuna. - he looked back (XIV, 6).

o inana aleamo duka $i$ tawo. - their mother dived back into the sea $(\mathrm{XV}, 91)$.

2. Rising pitch-accent: the pitch of the last vowel begins nearly as high as the second last vowel but rises sharply. This type is characteristic for interrogative sentences (symbol: ?).

inda amapimapii? - are they not ill? (IV, 11). opeamo ikarajaa? - what should he do? (XIV, 15).

3. Level-pitch-accent: the last vowel has the same pitch as the second last vowel or is slightly lower. This type of accent is characteristic for exclamatory sentences (symbol: !).

33) Of course in Wolio, like in other languages, greater entities of utterance are found. But these do not show the functional, systematical and obligatory character of the sentence. A greater entity is, from a linguistic point of view, only a series of sentences. 
He sabaqka! - Say comrade! (XIV, 22).

Pasumpuakea uwe! - Let him drink water! (XV, 34).

4. Falling pitch-accent: the pitch of the last vowel begins as high (or nearly as high) as the pitch of the second last vowel and then slightly falls. This type indicates that a further sentence is to follow. This "suspensive" accent is especially used when a quotation follows (symbol: :).

aabakimo mopebuanina sumai: "Inda ukamata iqkomiu o barwine aliqkaaka taqi i arei?" Alaranimo mopebuanina sumai: "Takamata $i$ arri". - They asked these fishermen: "Did not you yesterday see a woman who walked along weeping?" The fishermen answered: "We did see yesterday" (XV, 56-59).

5. 2. (2). The sentence-intonation is the pitch-relation of the phrases constituting the sentence. It has 5 types:

a. Rising intonation: the pitch of the phrases rises gradually, the pitch of each phrase being slightly higher than the pitch of the preceding phrase.

b. Level-rising intonation: the first two or more phrases have the same pitch, the following phrases show the rising intonation described under $a$.

c. Broken intonation: the sentence begins with rising intonation (a) but suddenly comes to a stop and after a pause it goes on again, starting with the same pitch as the first phrase (symbol:,).

d. Linked intonation; the intonation is the same as the broken intonation (c.) except in the last phrase before the pause which has falling pitch on its last vowel (symbol:,).

e. Level-intonation: all the phrases have equal (or nearly equal) pitch. About the combination of intonation and sentence-accent it may be remarked that all combinations occur except that of levelintonation with low pitch, rising pitch, and falling pitch-accent. It follows that level-intonation only occurs in exclamatory sentences. The intonation may be interrupted when a vocative is intercalated. The vocative has a relatively low pitch (symbol:,-,).

Ko iqkoo, Ndokendoke, pia ntakemo? - and you, Monkey, how many leaves? (XIII, 12).

Coordinate substantive-phrases have similar pitch so that a temporary level-intonation is inserted (symbol:,). As already has been remarked (see: 5. 1., E.), such a series of coordinate substantive-phrases is concluded by a te-, atawa-, or ara-phrase with which the original intonation is resumed. 
Apeqkaadariaka baca, buri, tanu, posorumba, pesulasula te 'ámala - They learn reading, writing, weaving, sewing, embroidery, and contemplation (IV, 35).

Motandakina, moposusuna ara moposuona apadamo uka akokariaaakea - They also stop holding feast for those who are circumcised, those whose ears are pierced, and those who are locked up (V, 24).

Kariaa padamo atopatantu wakutuuna, incia kananeana $i$ kariaa kazera humai daaqia uka o tandakia, posusua atawa posuoa When the time of the feast has been fixed, usually circumcision, ear-piercing or locking up are combined with the weddingfeast $(\mathrm{V}, 5)$.

Incidental deviations of intonation are mostly found in exclamatory sentences, e.g. :

Kaluntuna o mia sii! - How lazy this man is!

in which the first word has abnormally high pitch combined with stress.

5. 2. (3). A sentence usually contains a predicate which may be a substantive-phrase, a preposition-phrase, or a finite verb-form. When the predicate is a substantive-phrase or a preposition-phrase, the sentence always also contains a subject, whereas in sentences having a verb-phrase as predicate the subject is at least indicated by the actorprefix.

The most important exceptions are:

a. Fragmentary sentences in which elements are "lacking" which are sufficiently denoted in a preceding sentence, e.g. an answer to a question and the like.

Santakemo - One leaf (XIII, 11).

Mincuana gola, o raa! - It is no sugar, it is blood! (XIII, 47).

$b$. Sentences containing fixed expressions, titles of a story etc.

Umbe - Yes.

Aai - I don't know (XII, 14).

Taqkanapo - That is all (VII, 28).

Tulatulana Lowenlown Morikana - The story of Old-Lowulowu (X, title).

c. Some exclamatory expressions, vocatives, series of phrases used in counting, etc.

Karombuna Ulouloqkobulu ndea! - How bad Hairy-Caterpillar is! (XII, 40).

He sabaqka! - Say comrade! (XIV, 22). 
Sambaa, rua mbaa.... - One, two.... (XIV, 36).

A finite verb-form without an actor-prefix occurs in the following cases :

1. Imperatives :

Iqka papesua dadi! - Come on, put me in, if you dare! (XII, 42). Mai sapo, Ulouloqkobulu! - Do come down, Hairy-Caterpillar (XII, 45).

Taburakaakaakupo sagaa te iaku, Ndokendoke! - Drop some for me also, Monkey! (XIII, 20).

2. Impersonal verbs denoting meteorological phenomena etc.:

Koeo - The sun is shining.

Korerao - It is raining.

But these verbs may also occur with the actor-prefix of the $3 \mathrm{~d}$ person: akoeo, akowao, etc., e.g. :

Daaqia saaqu wakutuu akowao maranca - Once upon a time it was raining very hard (XIII, 1 ).

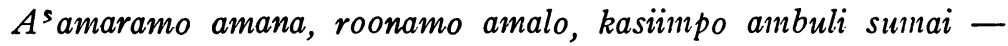
Their father was angry because it was evening by the time they returned $(\mathrm{XV}, 100)$.

As already has been mentioned (see the note to 5. 1. D.) the actorprefix of the $3 \mathrm{~d}$ person may be absent when the subject is mentioned within the same phrase as the verb. But this is never the case when this verb is predicate.

5. 2. (4). When the predicate is the first phrase of the sentence, the intonation is rising. But when one or more phrases precede the predicate, the intonation is level-rising, the predicate being the phrase where the rising part of the intonation begins.

It may be said in general that all phrases preceding the predicate are slightly emphasized. In fact many attributes which play an important role in the meaning of the sentence because of their meaning (which may be modal, local, temporal, or the like) always precede the predicate. There is no need to list them all here as numerous examples are found in the texts. But some of them need a special discussion:

$a$. Phrases with $k o$ and phrases with ne, ande, or ane (see 5. 1. F.) show the peculiarity of having always falling pitch on their last vowel. In interrogative sentences a ne-phrase may follow the predicate. This is connected with the preference of such sentences for having the predicate as the first phrase.

Opea ikarajaa, ne daaqia te kareia? - What is done when there is a wedding? $(\mathrm{V}, 1)$. 
b. A phrase containing a verb-form with prefix sa- usually is the first phrase of the sentence. It may be followed by a noun-phrase denoting the subject of the $s a$-form. When this is the case an attribute otherwise being a part of the phrase containing the $s a$ form may follow in a separate phrase.

Sabarina o ikaneku iaku kumbulimo katauku ara La Hoohoo ambulimo duka, roonamo indamo kukamatea - When I had much fish I returned, for I thought that Heron had perhaps also returned as I no longer saw him (XII, 16).

Saturerna o buluna panina apolakamo La Hoohoo ambulimo $i$ banuana - when the feathers of his wings had grown, Heron flew back home (XII, 23).

Sakawana o La Ndokendoke i banuana kawea amakasu amalo, amaimo inana La Hoohoo aabaki La Ndokendoke i apaimo La Hoohoo, ka indapo ambuli - After Monkey had come home, when evening was near, Heron's mother came to ask Monkey where Heron was, for he had not yet returned (XII, 13).

Samapupuna o loka masasa sumai akandea La Ndokendoke asabumo $i$ weta marumpurumpuna, lausaka akana $i$ ampa itaana La Kolokolopua - After Monkey had eaten up all the ripe bananas he jumped down on the grassy side and immediately came down on to the man-traps set up by Tortoise (XIII, 30).

As the given examples show the subject of the $s a$-form is usually mentioned when it is not the same as the subject of the sentence.

c. Sometimes the predicate is preceded by a noun phrase corresponding to the suffix $-n a$ attached to the subject following the predicate:

Incana kaadari incia humai abari mpun o waranaana - The contents of the schooling is very varied (IV, 27).

$O$ buri Walanda inda abari momakidana - There are not many who know Roman characters (III, 2).

Onina maqa mancuana kooni o Lozerulower $i$ piano itu daaqia sareriliqa adencu maqa miana - The old people tell that once upon a time people left Lowulowu $(\mathrm{X}, 1)$.

5. 2. (5). As already has been said above the subject of a sentence having a verb as predicate is expressed by the actor-prefix of the verb. If the subject is mentioned explicitly, it constitutes a separate phrase. This phrase usually is a substantive-phrase.

So umboombooremo itu komiu maasiakea o andimu, roonamo iaku bekuliqkamo, karana o amamiu alabi kawolena te iqkomiu - You 
stay here, be kind to your brother, for I am going away, because your father esteems his cleaned fish more than you (XV, 27).

But it may also be a verb-form:

Potalatala adi komiu, mamudaakana amalape kugagarikomiu You go and lie next to each other in order that I can count you well (litt.: that I-count-you be good) (XIV, 32).

When the predicate is a substantive-phrase or a preposition-phrase the subject is always mentioned (except in fragmentary sentences, see 5. 2. (3), a.).

When this subject is a participle the sentence usually suggests that the chosen predicate stands in strong opposition to another possibility.

Somo susuna indapo mokoonana - Only her breasts were not yet scaly (in distinction to other parts of her body) (XV, 94).

Taqkanapo sambaa molapana - Only one escaped (XII, 31).

$O$ ndokemo duka mohobutina buluna panina La Hoohoo sumai molapana - The same monkey that pulled out Heron's wingfeathers was the one who escaped (XII, 32).

Accordingly this type of sentence is especially used in interrogative sentences, because the essence of the question is preferably expressed by the predicate at the very beginning of the sentence.

Opea sadia ikandena maqa? - What do they usually eat? (I, 3). I apai maqa sabaqkamiu, ka inda kukamatea? - Where are your comrades, for I don't see them? (XIV, 23).

Opea ikarajaa ne daaqia te kazria? - What is done when there is a wedding? $(\mathrm{V}, 1)$.

As shown by the examples given the subject usually follows the predicate. But it precedes when it is emphasized even when this emphasis is very slight.

Maka iqkoo umempili - But you were fastidious (XV, 41).

Incia o amata alabiaka kawolena te iqkita - Our father esteems his cleaned fish more than us $(\mathrm{XV}, 42)$.

Andiku La Mbatambata, iaku Wa Turuqkoleo - My brother is La Mbatambata, I am Wa Turuqkoleo (XV, 47).

5. 2. (6). When the predicate is a transitive finite verb-form the object may constitute a separate phrase. This phrase usually follows the predicate but it precedes when it is emphasized.

Garaaka ndea, Mbatambata, o inata sii abencibencimea o bianaTruly, Mbatambata, there our mother has torn her sarong $(\mathrm{XV}, 39)$. 
O Wa Turuqkoleo akembaia $i$ saripina - She called Wa Turuqkoleo to her side $(\mathrm{XV}, 24)$.

$O$ bajuna abencibencimea duka - Her jacket she also tore up (XV, 51).

The emphasis of an object preceding the predicate is stronger than the emphasis of a subject in similar position, because an object constituting a separate phrase is already slightly emphasized even when it follows the predicate, as an object without any emphasis is part of the verbphrase (see 5. 1. $C, 4$.).

When subject and object both are mentioned in separate phrases, the one which is most emphasized precedes the predicate, the other follows. When neither of them is emphasized they both follow the predicate (which then has the greatest emphasis), the subject preceding the object.

O La Musa abawea o boku sii - La Musa brings this book.

O boku sii abawea o La Musa - This book La Musa brings.

Saeona malomalo atambimea Wa Turuqkoleo o La Mbatambata, aliqkamo apeelo inana - Next morning Wa Turuqkoleo carried $\mathrm{La}$ Mbatambata and went to look for her mother (XV, 36).

Lausakamo aalea amana o ikane sumai - At once their father took the fish $(\mathrm{XV}, 82)$.

As shown by the examples the verb usually has the object-suffix when the object is mentioned in a separate phrase (cross-reference). But this is not always the case. The object-suffix is absent when the object is strongly emphasized.

Taraqo opea? - What should we have heard? (XIV, 25).

Akamatamo o hariman igauna $i$ saao itu - He saw the tiger he had just tricked (XIV, 7).

O Wa Turuqkoleo te La Mbatambata so adaren saide - To Wa

Turuqkoleo and La Mbatambata he only gave a little bit (XV, 83):

The object usually is a substantive-phrase, but it may also be a phrase showing the same construction as a sentence. Such a phrase may begin with $o$.

Inda amatana $i$ apai apalai - He did not know where he was running (XIV, 10).

Maqa zentitinai aumbamo aporomoromu apoganaka naipiamo $o$ kariaa humai te opea beikaraja - The relatives then gather in a meeting and discuss, when the feast will take place and what will be done $(\mathrm{V}, 3)$.

Aabakimea o opea inda ikobuluakana panina sumai - She asked 
him how it happened that he had no longer any wing-feathers (XII, 19).

5. 2. (7). A sentence may contain a series of phrases which shows the structure of a sentence but is in its whole an attribute to the predicate. When such a sentence-like series of phrases precedes the predicate it has linked intonation and may be introduced by such words as moomini - although, karea - when, baraqkala - if, etc.

Amapupu biana, abencibencimo bajuna - When her sarong was used up she tore up her jacket (XV, 30).

So amaqulemo alagu o Wa Turuqkoleo, indamo abaqu o inana Although Wa Turuqkoleo tired herself out with singing, her mother did not come up (XV, 102).

Moomini kukembaia, amendeu aose iaku. - Although I called him, he did not want to come with me (XII, 15).

Kawa o La Kolokolopua aalamo pilita, aalamo puuna - When Tortoise made his choice he took the trunk (XIII, 8).

Baraqkala aanuko mia, daampo kupapakia - If anyone would tease you, I shall certainly bite him (XII, 4).

When such a sentence-like series of phrases follows the predicate, it has broken intonation and may be introduced by such words as $k a-$ then (see 5. 1. F, 2.), kasiimpo - then, mamudaakana - in order that, pokareaaka - until, roonamo - because, sababuna - because, karana - because, madaakana - because, maka - but, tabeana - but, sampe - till, etc.

Karea amalo, La Mbatambata samaloa ataqiaka inana, amatuumo borokona - At night La Mbatambata cried all the night for his mother, his throat being dry (XV, 33).

Lausakamo aalea amana o ikane sumai, kasiimpo anasua, ka akande - At once their father took the fish, then cooked them and then ate them up $(\mathrm{XV}, 82)$.

Aemanimea, mamudaakana aose Walanda humai, roonamo onina beakambelimbeliakea, mamudaakana apokamakamataakea miana dunia - He asked him to go with that Dutchman, because he would go travelling with him, as he said, to show him to the people of the world (XI, 20).

Saeo saeo tuamo itu apogoraaka maqa, pokawaaka amate o lokana La Ndokendoke - Each day they called out to each other like this, until Monkey's banana died (XIII, 14).

Alawanimo La Hoohoo amendeu asapo, roonamo amaeka, saba- 
buna daaqia amakidikidi - Heron answered that he did not want to go down, because he was afraid, as he was small (XII, 2).

So umboombooremo itu komiu maasiakea o andimu, roonamo iaku bekuliqkamo, karana o amamiu alabi kawolena te iqkomin - You just stay here, be kind to your brother, for I am going away, because your father esteems his cleaned fish more than you (XV, 27).

Garaaka ndea, Mbatambata, o inata sii abencibencimea o biana, madaakana iqkoo $i$ awi umempili ukande - Truly, Mbatambata, there our mother has torn her sarong because you were so fastidious in eating yesterday $(\mathrm{XV}, 39)$.

Adarumea ikane o inana, maka amendeu so ataqi arambirambitaka karona, tabeana beakande kawolena amana - His mother gave him fish, but he refused. He just cried beating about his body, but he wanted to eat his father's cleaned fish $(\mathrm{XV}, 13)$.

Temo aala parewana tanuana inana La Mbatambata, kasiimpo abebeaka inana La Mbatambata, sampe amakatukatu - And he took the weaving-loom of La Mbatambata's mother, then he hit La Mbatambata's mother with it till it broke (XV, 21). 


\section{TEXTS}

I.

1. Pia mpearo saeo akande maqa mia i Wolio?

2. Maqa mia $i$ Wolio akande talu mpearo saeo.

3. Opea sadia ikandena maqa?

4. Ikandena maqa $i$ nuncana talu mpearo humai apokanakana.

5. O malomalo akande jepe atazea o bae ara o kaitela.

6. Pontaqaeo o bae, kaitela ara rikau.

7. O malo himbomo uka humai.

8. Ikandena uka o ikane, o tawana kau ara naqa kamatuu.

II.

1. Pia ruliqa o daoa $i$ Baubau sa'ahadi?

2. O daoa saeo saeo $i$ Baubau.

3. Opea iasona maqa mia?

4. Maqa mia aaso sagala giu: bae, kaitela, wikau, tagambiri, paqana, tabako, matigi, kapulu, ndamu, paqawa, rabuta, bajubaju te sagiu sagiuna.

5. Abari uka o mia moninaakana $i$ sambali?

6. Abari. Aminaaka i maqa kampokampo.

7. Aminaaka $i$ karidoana maqa mia humai?

8. Umbe, sagaa talu pulu kilo karidona.

9. Sagaa akole $i$ dala.

10. Akaliqkaliqka maqa?

11. Umbe, sagaa abuntubuntuli.

12. Inda amaqule maqa?

13. Amaqule uka, roonamo takamatea akahaahaa.

14. Maka akawa uka i kawaana.

III.

1. Abari o mia momakidana abaca ara aburi?

2. O buri Walanda inda abari momakidana.

3. Taqkanamo buri Wolio te buri Maqgasa abari. 


\section{I.}

1. How may times a day do the people in Wolio eat?

2. The people in Wolio eat three times a day.

3. What do they usually eat?

4. Their food is the same these three times.

5. In the morning they eat rice-milk, rice or maize.

6. At noon rice, maize or cassava.

7. The same in the evening.

8. Fish, vegetables or shellfish they also eat.

II.

1. How many times a week is a market held in Baubau?

2. There is a market in Baubau every day.

3. What do the people sell?

4. People sell all kinds of things: rice, maize, cassava, gambier, areca, tobacco, lime, choppers, axes, sails, cords, garments, etc.

5. Are there many people who come from the country?

6. Yes, they come from the villages.

7. Do those people come from far?

8. Yes, sometimes from a distance of thirty kilometres.

9. Sometimes they sleep by the roadside.

10. Do they go by foot?

11. Yes, sometimes in jog-trot.

12. Do they not get tired?

13. They do indeed get tired, for one sees them pant.

14. But still they reach their target.

\section{III.}

1. Are there many people who can read or write?

2. There are not many who know Roman characters.

3. But there are many (who know) Wolio and Macassar script. 
4. Saopea kabarina sikola $i$ Wolio?

5. Kabarina sikola $i$ Wolio himbo itu daaqia nama pulu aqu.

6. Sikola humai o sikolana pamarinta?

7. Umbe, baribaria sikolana pamarinta.

8. Taqkanamo rua aqu mincuana.

9. Saaqu sikolana Zending ${ }^{34}$ ), saaqu sikolana $\mathrm{Missie}^{34}$ ).

1. Daaqia te anata?

2. Umbe, daaqia pata mia.

3. O aka o umane atawa o bazine?

4. O aka o bawine.

5. Maka inda baribaria o barine?

6. Inda, rua mia o bazine te rua mia o umane.

7. Asikolamo?

8. Umbe, rua mia, rua miana indapo.

9. Saopeamo o 'umuruna o andi?

10. $O$ sumuruna o andi lima mbulamo.

11. Inda amapimapii?

12. Baribaria daaqia amalamalape.

13. Apeelu sadia akande?

14. Umbe, sadia apeelu maqa akande.

15. Maqa anaana amahaqa uka sagaa?

16. Sadia amahaqa.

17. Sadia inda araqoni.

18. Ne inda araqoni atobemba maqa?

19. Umbe, atobemba.

20. I Wolio abari uka maqa anaana atobemba?

21. Abari, maka abariaka i piamo itu, roonamo i piamo itu kadaaqiana lipu aposalamo te siisii.

22. Roonamo i piamo itu maqa mia daaqia akeniaka mpun o sadati maqeqe.

23. Maqa anaana atogurudii mpuu.

24. O bawine atawa o umane apokawaaka kaadari porikana, kasiimpo amembali asapo $i$ tana.

25. Himbomo maqa anaana umane, amakidapo mpuu, kasiimpo atorambasaka.

34) As these words are pronounced as foreign words, they are given here in their original Dutch spelling. 
4. How many schools are there in Wolio?

5. As to the number of the schools in Wolio, there are sixty.

6. Are these government-schools?

7. Yes, they are all government-schools.

8. Only two are not.

9. One is a (Protestant) mission-school, the other is a (Catholic) mission-school.

\section{IV.}

1. Have you any children?

2. Yes, (there are) four.

3. Is the oldest a boy or a girl?

4. The oldest is a girl.

5. But they are not all girls?

6. No, two are girls and two are boys.

7. Do they go to school?

8. Yes, two do, two others not yet.

9. How old is the youngest?

10. The youngest is five months old.

11. Are they not ill?

12. They are all quite healthy.

13. Have they got a good appetite?

14. Yes, they always want to eat.

15. Are the children ever naughty?

16. They are always naughty!

17. They are never obedient.

18. When they are disobedient, are they then punished?

19. Yes, then they are punished.

20. Are children often punished in Wolio?

21. Yes, but formerly more often, for in olden times the situation of the country was different from now.

22. For formerly people held fast very much to the old customs.

23. The children are kept very much under control.

24. A girl or boy is first taught, afterwards they may go out.

25. As to the boys, when they are very clever, one lets them go. 
26. Incia reakutunna torambasaka humai, apoolimo atosaroqi amembalimo ajagani karona.

27. Incana kaadari incia humai abari mpun o zearanaana.

28. Kaadarina bawine sagiu uka, kaadarina umane sagiu uka.

29. Opea apeqkaadariaka o maqa anaana humai?

30. Baabaana o sadati, kasiimpo o agama, kasiimpo poewaqi.

31. Ko maqa bawine apokana o kaadarina?

32. Aposala, roonamo maqa barine abari ambooreaka $i$ banua.

33. Apeqkaadariaka sadati te agama.

34. Kasiimpo aposala o kaadarina maqa Wa Ode te kaadarina maqa barine mosagaanana.

35. Apeqkaadariaka baca, buri, tanu, posorumba, pesulasula te sámala.

V.

1. Opea ikarajaa ne daaqia te karwia?

2. Baabaana atopaumba maqa zentitinai kooni daaqia te haejati apakawi.

3. Maqa zutitinai aumbamo aporomuromu apoganaka naipiamo o kariaa humai te opea beikarajaa.

4. Pada humai aposambulimo uka samia samia $i$ banuana, mamudaakana apepuu amakakauaka kariaa humai.

5. Kariaa padamo atopatantu wakutunna, incia kananeana $i$ kariaa karia humai daaqia uka o tandakia, posusua atarea posuoa.

6. Incia mpun akazemo wakutuuna, aposaumbamo maqa zentitinai ara maqa sabasabaqka apohambahamba.

7. Sagaa mopakaronamo galampa, sagaa mobelokinamo banua, sagaa mobazanamo kahambana.

8. Morambina ganda daaqianio uka.

9. Ne akawamo r'akutuuna moporikanana o posuoa.

10. Wakutuuna atopaumba maqa bawine humai kooni atosuo, wakutuunamo uka humai atorambi o ganda.

11. O siimo o kapepunana o kariaa.

12. Incia lima malo o ganda saeo saeo atorambi.

13. O kariaa incia sii apooli atopadaaqia $i$ umane mokarei ara $i$ bawine ipakari humai.

14. Motopaisilamuna atosuomo uka.

15. I nuncana zuakutuuna kariaa humai saeo saeomo aumbamo o mantomu.

16. Aumbaaka mantomu atorambiakamo uka ganda. 
26. That is the moment that they are let free, when one can say they are able to look after themselves.

27. The contents of the schooling is very varied.

28. The schooling of the girls is different from that of the boys.

29. What are the children taught?

30. In the first place the adat (customs), then religion, then fighting.

31. And the girls are they taught the same?

32. It is different, for the girls usually live at home.

33. They are taught adat and religion.

34. Then the schooling of the Wa Ode (women belonging to the nobility) is different from that of the other girls.

35. They learn reading, writing, weaving, sewing, embroidery, and contemplation.

$$
\mathrm{V} \text {. }
$$

1. What is done when there is a wedding?

2. First the relatives receive an announcement that there is a plan to arrange a marriage.

3. The relatives then gather in a meeting and discuss when the feast will take place and what will be done.

4. Afterwards everybody returns to his own home in order to begin preparing the feast.

5. When the time of the feast has been fixed, usually circumcision, ear-piercing or locking up (of girls) are combined with the weddingfeast.

6. When the time has come, the relatives or friends come to help.

7. Some build the galampa (temporary building for a feast), others decorate the house, yet others bring their contribution with them.

8. The drummers are also present.

9. What comes first, when the time has come, is the locking up.

10. When those girls are told that they are to be locked up, the drums are beaten at the same time.

11. That is the beginning of the feast.

12. Then for five days the drums are beaten every day.

13. The feast can be held at the bridegroom's or at the bride's (house).

14. They who are to be circumcised are also locked up.

15. During the feast contributions come in every day.

16. While the contributions are carried in, the drums are beaten for them. 
17. O kariaa $i$ bawine, o umane aumbamo $i$ banuana kariaa humai.

18. Iwe humai o umane atopakawi wakutuuna matana.

19. Maqa posusuna te motandakina wakutuuna matana humai atopaajomo uka, kasiimpo atobawa i galampa.

20. Kasiimpo apada humai, atopambulimo maqa anaana humai.

21. Apadamo. O miana galampa adaremea pasali.

22. Maqa mia i banuana kariaa atopasalimo uka.

23. Pada o pasalia humai, maqa mia motokembana humai aposambulimbulimo.

24. O kariaa apadamo. Motandakina, moposusuna ara moposuona apadamo uka akokariaaakea.

25. Maka o mia mokawina humai ambooremo i banuana barine lima malo kaqeqena.

26. Pada humai, kasiimpo amembali asapo $i$ tana.

27. Maka taqkanapo o umane porikana mosapona.

28. Asapo $i$ tana humai, umane ambuli $i$ banuana sabantara, kasiimpo ambuli i banuana bawinena.

29. Ambuli humai, abawamo kambakamba itobena $i$ dala abakuaka $o$ bazinena.

30. O kambakamba humai agiugiumo o zearanaana.

31. Sagaa o dali, kalo ara o siqkaru maliqumo ipeeluna o umane humai.

32. Pada aumbaaka kabaku humai, o barine amembalimo uka aliqka akambelimbeli.

33. Akambelimbeli incia sii aliqka $i$ banuana umane akole ara pia malo maliqumo kapeeluna maqa.

34. Pada humai amaliqumo peepecluana $i$ apai aliqka.

35. Amapupumo uka o sarasarana kariaa humai.

VI.

1. Ne akawamo heqgana beaumbamo o anaana atokembaakamo o bisa.

2. Sagaa aumbamo uka maqa rentitinai.

3. Atobusaaka o anaana humai atopekaqkilomo atobahomo.

4. O lolaina atododo.

5. O akana atodikamo $i$ nuncana kaluku. 
17. If the feast is at the woman's (house), the man comes to the house of the feast.

18. There the man is married at the climax (of the feast).

19. (The girls) whose ears are pierced and (the boys) who are circumcised are supplied with fine cloth during that climax, then they are led into the galampa.

20. When that is done, these children are sent back home.

21. It is finished. The people of the galampa are given a festive gift.

22. The people of the house of the feast also get a festive gift.

23. After the giving of the festive gifts the invited guests all go home.

24. The feast is finished. They also stop holding feast for those who are circumcised, those whose ears are pierced, and those who are locked up.

25. But the bridal pair remains in the woman's house for five days.

26. Then they are allowed to go out.

27. But only the man goes out first.

28. When he has gone outside, the man returns to his home for a while, then he returns to the house of his wife.

29. On his return he brings flowers with him picked along the roadside and gives them to his wife.

30. Those "flowers" are of various kinds.

31. Sometimes earrings, a necklace or a ring, whatever the man likes.

32. After he has brought that gift, the woman may also go out walking.

33. This walk consists of going to the man's house and sleeping there as many nights as they like.

34. Then they may go where they want to.

35. The ceremonies of the feast are also finished.

VI.

1. When the time comes that a child is about to be born, a midwife is called.

2. Sometimes the relatives also come.

3. When born, the child is cleansed and bathed.

4. The navel-string is cut.

5. The afterbirth is put into a coconut. 
6. O kadodona lolai ne $i$ kampo adodoakea lumai te apetandoa $i$ siqkaru.

7. O sii o sarasaranamo uka.

8. Pada atopekaqkilo, o anaana humai atobaquakamo.

9. Sagaa maqa anaana atosaqo inda atotauraka $i$ lante.

10. O sii o kapoolina samia samia.

11. O anaana humai apakolea $i$ kumba kooni indaaka amaisia Kabinduboroko te adikaakea uka o kapulu ara o piso i saripina.

12. I totona baana adikaakea o paiasa.

13. O sii kooni podomo kajaganina Seetani indaaka amai ahaqahaqai o anaana humai.

14. O anaana maidiidi humai sagaa saumbana atopakandemo, sagaa uka so daaqia atopadudu ara pia mbula.

\section{VII.}

1. Ne daaqia te momatena atoparmbamo maqa rentitinai.

2. Amaimo apokareakazea apoganaka opeamo ikarajaa, maqa incemamo mobahoa, incemamo mobacaakea talakii.

3. Amambotuaka apepuumo maqa akarajaa.

4. Daaqiamo mobencina balu, mokarajaana maiasa, mokarajaana kapatea, mokarajaana dopi te mopekarakarajaana i nuncana banua, mobahona maeati temo mo'urusuna kinande.

5. I koburu aselimo uka maqa mia o tana.

6. Karwaka rakutunna o kapatea atobareamo $i$ koburu.

7. Maka baabaana o maeati atosambaheaaka sagaa $i$ banua matea humai, sagaa uka atobawa $i$ masigi.

8. Apadaaka abazeamea $i$ koburu, sadia aratibuakea.

9. Aumbaaka i koburu atolamuimo o mia mate humai.

10. O balo humai abubuakea bia maputi.

11. Kasiimpo o maeati atotau $i$ nuncana kabaloqko.

12. O maqa mia molazatia $i$ kabaloqko humai podomo momarampina $i$ momatena humai.

13. O maeati humai atodikamo i diqkanana.

14. O maeati ataburi kaanana.

15. Kasiimpo atoaroni o kabokena,

16. Pada humai atutubimea o balo humai te dopi. 
6. The cutting of the navel-string, if done in a village, is performed with a sharp piece of bamboo and a ring is used to lay it on.

7. This is a custom.

8. When the child has been bathed, a prayer is said for it.

9. Usually children are held in one's lap and they are not laid down on the floor.

10. That is to be decided by everyone.

11. The child is put to sleep in a kumba (young leaf-sheath of a banana-tree), it is said in order that it may not be visited by a "Pull-throat" (a kind of demon), and a chopper or a knife is laid beside it.

12. Near the head a mirror is put.

13. These are all said to be only protections against demons in order that they will not come and plague the child.

14. The child is given food immediately after birth, or else it is suckled for some months.

\section{VII.}

1. When someone has died, the relatives are informed.

2. They come together and discuss what is to be done, who are to wash him, and who shall recite the talqin for him.

3. When a decision has been reached, they set to work.

4. Some tear the shroud, some make the grave-tablet, some make the litter, some make the board and some do odd jobs in the house, soms wash the corpse and others organize the meal.

5. In the graveyard people dig into the ground.

6. When the time has come, the litter is carried to the graveyard.

7. But first a salăt is performed for the corpse, sometimes in the house, sometimes he is brought to the mosque.

8. Then he is carried to the graveyard, continuously religious formulas being recited for him.

9. When arrived at the graveyard, the corpse is put into the ground.

10. The grave is covered with a white cloth.

11. Then the corpse is laid down into the grave.

12. The people who receive him in the grave, are all close relatives of the dead man only.

13. The corpse is laid in its place.

14. The corpse is laid on its right side.

15. Then his tapes are loosened.

16. Then the aperture is closed with the board. 
17. Aposapenepenemo maqa mia $i$ bawo.

18. Somo samia momboorena mobacana dosa.

19. Pada abaca, akompamo uka incia.

20. Kasiimpo o balo humai atumbuniakamea tana.

21. Abukeaka adikaakamea o maiasa $i$ totona baana mia mate humai.

22. Ne umane momatena saaqu o maiasana.

23. Ne o bawine rua aqu o maiasana.

24. Pada adika o maiasa abuburiakamea o buqabuqa te abubusiakamea urve ido'a o koburu humai.

25. Padaaka humai abacaakamea talakii.

26. Kasiimpo aposambulimbulimo maqa mia humai $i$ banuana.

27. Sagaa ambulimo $i$ banuana mate humai, roonamo daaqia abaca malona.

28. Taqkanapo.

VIII.

1. Daaqia opuamami, ne apebaho apcbaho o uwe pitu gusi kabarina.

2. Maka o incia humai samiamiana uka.

3. Ne pada apebaho o karona kabilaqa himbo paiasa.

4. Maliqu kapeqkenisana ne pada apebaho humai adikaakea o bia maputi, mamudaakana inda akeni maqa kapeqkenisa ara maqa rindi ipadana uka ikenina maqa mia.

5. Himbomo sii o tulatulana.

IX. Tulatulana o 'Arabu makida.

1. Daaqia samia o 'Arabu o haji.

2. Abariaka mia i daoa apatiumbamo o kakidana.

3. Makasuaka soo eo akembamo maqa anaana, kasiimpo atumpua akamata $i$ nuncana mbalombalo.

4. Incana humai uka asapomo o eo.

5. Ne maqa anaana akamata i nuncana mbalombalo humai sadia duka akamata daaqiapo te eo.

6. Sampe o 'Arabu humai atomaroboakamo te atopujimo kooni: "Amakida!"

7. Sampe o habara incia sii akawamo uka $i$ kamali.

8. Maka amentemo oputa o apokia 'Arabu humai apatipatiumba kakidana $i$ kabariana mia.

9. Saeoakana uka o'Arabu humai aromusakamo uka maqa anaana $i$ daoa. 
17. The people in the grave come up.

18. Only one remains, who says prayers.

19. After he has finished, he also climbs out.

20. Then the grave is filled with earth.

21. When it is full, they place the grave-tablet at the dead man's head end.

22. When the dead person is a man, there is one grave-tablet.

23. When it is a woman, there are two.

24. When the grave-tablet has been set up, they scatter flowers on the grave and sprinkle it with holy water.

25. Then they recite the talqin over it.

26. Then people all return home.

27. Sometimes they return to the dead man's house, because a funeral meal is held.

28. That is all.

VIII.

1. Once upon a time there was an ancestor of ours who, when he bathed, used seven tubs of water.

2. But he was not an ordinary person.

3. After he had bathed, his body was like a mirror.

4. All things which he might touch, were covered for him with white cloth, when he had bathed, in order that he would not touch railings or walls which people had touched already.

5. This is his story.

IX. The story of a clever Arab.

1. Once upon a time there was an Arab, a hajji.

2. When there were many people at the market, he demonstrated his cleverness.

3. When the sun was almost setting, he called the children and then told them to look into a bamboo.

4. In the meantime the sun had set.

5. When the children looked into the bamboo, they saw that the sun was still there.

6. Consequently the Arab was much discussed and was praised with the words: "How clever he is!"

7. So the tale also penetrated to the palace.

8. Now the ruler wondered why that Arab continuously demonstrated his cleverness in public.

9. One day that Arab again gathered the children at the market. 
10. Sasoona uka eo atumpumea maqa anaana humai akamata $i$ nuncana mbalombalo humai te apaumbaia: "O eo padamo uka kudikaia $i$ mbalombalo sii.

11. Kamatamea sii itu!"

12. Maqa anaana humai akamatamo.

13. Maka o eo inda atokamata $i$ nuncana mbalombalo humai.

14. Sabutuna akoonimo maqa anaana humai: " $K a$ inda takamatea $o$ eo, taqkanamo randana aena oputa!”

15. O'Arabu humai inda aparacaea.

16. Akamatamo uka.

17. Maka so uka akamatamo himbomo ikamatana maqa anaana humai.

18. Sakamatana humai apenemo i kamali aemani masafu.

19. Himbomo humai tulatulana.

X. Tulatulana Lownilowu Morikana.

1. Onina maqa mancuana kooni o Lozulozen $i$ piamo itu daaqia sawuliqa adencu maqa miana.

2. Roonamo saeoakana sanampuu maqa mia agaamea maqa banuana, roonamo indamo atara maqa amboore i nuncana banua, roonamo o kampo humai ahumbunimea o kolo'uma.

3. Maka o kolo'uma incia sii inda apokana te maqa kolo' uma biasa sii, roonamo amaoge mpuu.

4. Ne apondele akotibuaka asombusombua maqa padana banua.

5. Sampe maqa mia harusumo agaaqia maqa o banuana, roonamo indamo atara amboore $i$ nuncana banua.

6. Amaekamo ataburia maqa kolo'uma maoge humai.

7. Sabutuna aliqkamo maqa amboore uka i tampa mosagaanana.

8. Mbakanamo o kaanuanuna maqa miana Lowulowu o tuamo sii:

9. Miana Lownlown sii ataburia o kolo'uma.

10. O siimo tulatulana o Lowulowu Morikana.

XI. Tulatulana La Damu Sarina.

1. Daaqia samia te anana.

2. O mia humai himbomo uka o mia mosagaanana.

3. Maka o anana humai samaogena aposalamo mpuu te maqa anaana mosagaanana.

4. Karona, limana te maqa aena sajulujuluna kaogena te kaaratena. 
10. After the sun had set, he told the children to look into the bamboo and said to them: "I have again put the sun into this bamboo".

11. „Look at this”.

12. The children looked.

13. But the sun was not to be seen in the bamboo.

14. So the children said: "But we do not see the sun, but only His Majesty our Lord".

15. The Arab did not believe it.

16. He also looked.

17. But he also only saw the same the children had seen.

18. When he had seen that, he went up to the palace to ask forgiveness.

19. So is his story.

X. The story of Old-Lownlowu.

1. The old people tell that once upon a time people left Lowulowu,

2. For one day people suddenly left their houses, because they could no longer bear staying in their houses as the village was overrun by snails.

3. But these snails did not resemble ordinary snails, for they were very large.

4. When they fell down as they crawled, they penetrated right through the roofs of the houses.

5. So the people were forced to leave their houses, as they could not stand staying in their houses.

6. They were afraid that those great snails would overwhelm them.

7. Therefore they went to live in another place.

8. That is why the people of Lowulowu are teased like this:

9. The people of Lowulowu are overwhelmed by snails.

10. This is the story of Old-Lowulowu.

XI. The story of La Damu Sarina.

1. Once upon a time there was someone who had a child.

2. That person was just like all other people.

3. But this child of his, when it was grown up, differed greatly from other children.

4. His body, his arms and his legs continually increased in length and size. 
5. Aposala mpun kaogena te kaogena mia.

6. Mbakanamo o mancuanana afikirimo: "Garaaka o anaku sii inda apokana te maqa anaana mosagaanana.

7. Amaoge mpuu o anaana sii!'

8. Mbakanamo akarajaamea, mamudaakana o anaana humai amakaaaka bukuna.

9. Saeo saeo atudaakamea batu.

10. Arambiakamea kau.

11. Amapasamo kaluku i baana.

12. Sampe o anaana humai indamo anamisia maqa kasikisaa humai.

13. Tee akolelemo uka $i$ Kota Wolio kooni daaqia te mia himbo o humai kaogena.

14. Sabutuna atopeelomo.

15. Apamembalimea kaose.

16. Sabutuna opuna humai ne alimba i umala indamo amabaho, roonamo o mia humai asodamo incia.

17. Rampana kalaqana indamo amabaho o aena opuna humai reakutuuna apolimba maqa.

18. Daaqia saeo aumbamo kapalana Walanda.

19. Akamatea daaqia te mia maoge humai.

20. Aemanimea, mamudaakana aose Walanda humai, roonamo onina beakambelimbeliakea, mamudaakana apokamakamataakea miana dúnia.

21. Apojanjimo: ne aumba uka sampearona, kasiimpo beabawea.

22. Maka garaaka rakutuuna aumbamo o mia maoge humai daaqiamo pia malo amate.

23. Jaji indamo akawa o haejatina o Walanda humai.

24. Himbomo sii tulatulana.

XII. O sii tulatulana La Ndokendoke te La Hoohoo.

1. Baabaana sii o La Ndokendoke asale La Hooho beasapo apenanda.

2. Alawanimo La Hoohoo amendeu asapo, roonamo amaeka, sababuna daaqia amakidikidi.

3. Akoonimo La Ndokendoke: "Opeamo umaeka?

4. Baraqkala aanuko mia, daampo kupapakia”.

5. Aundamo La Hoohoo asapo arako ikane.

6. Sakawana i tawo apeelomo ikane maqa.

7. Maka saopeapo La Ndokendoke apeelo ikane, inda apokawaaka. 
5. His size greatly differed from that of the people.

6. So his father thought: "Indeed, this child of mine is not the same as other children.

7. This child is very big!"

8. Therefore he did his best that the child should be strong.

9. Daily he threw stones at him.

10. He hit him with a stick.

11. A coconut would break on his head.

12. Consequently that child no longer felt these tortures.

13. And it became known in the palace about him that there was someone who was as big as that.

14. The result was that he was looked for.

15. He was made a "follower" (a kind of servant of the ruler).

16. So his lord, when coming to a river, did not get wet, because that man carried him on his shoulder.

17. Because of his length his ruler's feet no longer got wet when they crossed.

18. One day a ship of a Dutchman arrived.

19. He saw that there was such a big man.

20. He asked him to go with that Dutchman, because he would go travelling with him, as he said, to show him to the people of the world.

21. They agreed that, when he came back next time, he would take him with him.

22. But lo!, when he came, the giant had died a few days before.

23. So the Dutchman's plan fell through.

24. This is his story.

XII. This is the story of Monkey and Heron.

1. The beginning was that Monkey invited Heron to go down (to the beach) to fish.

2. Heron answered that he did not want to go down, because he was afraid, as he was small.

3. Monkey said: "Why are you afraid?"

4. "If anyone would tease you, I shall certainly bite him".

5. Then Heron agreed to go down to catch fish.

6. When they had arrived at the sea, they looked for fish.

7. But however intently Monkey looked for fish, he could not find anything. 
8. Roonamo akagusagusa apolanda i tawo, sampe apalai o ikane.

9. Incia La Hoohoo abarimo ikanena.

10. Karea apontaqa eo, amarewumo incana o La Ndokendoke.

11. Akeniakamo La Hoohoo, kasiimpo ahobuti buluna panina, kasiimpo aala ikanena, kasiimpo ambuli.

12. Incia La Hoohoo indamo apooli ambuli $i$ banuana, roonamo amapupumo buluna panina ahobutia La Ndokendoke.

13. Sakawana o La Ndokendoke i banuana karwa amakasu amalo, amaimo inana La Hoohoo aabaki La Ndokendoke i apaimo La Hoohoo, $k a$ indapo ambuli.

14. Alawanimo La Ndokendoke: "Aai, ka sakazeamami i tawo o La Hoohoo aliqkamo duka samiamiana.

15. Moomini kukembaia, amendeu aose iaku.

16. Sabarina o ikaneku iaku kumbulimo katauku ara o La Hoohoo ambulimo duka, roonamo indamo kukamatea".

17. Araqo incia sumai, o inana La Hoohoo apolakamo asapomo i tawo apeelo anana.

18. Sakazana i tawo akamatamea La Hoohoo so akabalebalemo indamo te buluna panina.

19. Aabakimea o opea inda ikobuluakana panina sumai.

20. Alawanimo La Hoohoo: ahobutia La Ndokendoke, incia o ikanena La Hoohoo apadea aalea La Ndokendoke.

21. Saraqona incia sumai amarerumo incana o inana La Hoohoo.

22. Abawamea $i$ nuncana lia o La Hoohoo, kasiimpo atautauakea kinande, pokawaaka atureu buluna panina.

23. Satureuna o buluna panina apolakamo La Hoohoo ambulimo $i$ banuana.

24. Sakaruana apogaugaumo maliqu hoo beasale maliqu ndoke beapckabaqkabaqka, mamudaakana beabolosiaka namisina La Hoohoo.

25. Alipamo La Hoohoo akemba La Ndokendoke beapekabaqkabaqka bealiqka arako ikane $i$ saaqu duka lizerto, roonamo kooni izve sumai abari o ikane.

26. Saraqona maqa ndoke baribaria aposaundemo.

27. Akarajaamo baqka maqa.

28. Samondona o baqkana sumai aposasarimo maliqu ndoke baribaria te maliqu hoo baribaria. 
8. For he walked over the beach with much noise, so that the fishes fled away.

9. But Heron got much fish.

10. When noon came, Monkey became angry.

11. He got hold of Heron, then he pulled out his wing-feathers, then he took away his fish, then he went home.

12. But Heron could not return home as the feathers of his wings had all been pulled out by Monkey.

13. After Monkey had come home, when evening was near, Heron's mother came to ask Monkey where Heron was, for he had not yet returned.

14. Monkey answered: "I do not know, for when we had reached the sea, Heron walked off alone.

15. Although I called him, he did not want to come with me.

16. When I had much fish, I returned, for I thought that Heron had perhaps also returned, as I no longer saw him".

17. When Heron's mother heard that, she flew down to the sea to look for her child.

18. Arrived by the sea she saw Heron standing up, not having anymore wing-feathers.

19. She asked him how it happened that he had no longer any wingfeathers.

20. Heron answered that Monkey had pulled them out and that Monkey had taken away all Heron's fish.

21. Having heard this Heron's mother grew angry.

22. She brought Heron into a cave and afterwards she let down food to him, until his wing-feathers had grown.

23. When the feathers of his wings had grown, Heron flew back home.

24. When he had arrived there, all herons discussed inviting all monkeys to go boating with them in order to take revenge for what Heron had suffered.

25. Heron went to call Monkey to come boating to go fishing on an other island, for there must be a lot of fish there.

26. Hearing this all monkeys agreed.

27. They made boats.

28. When the boats were ready, all monkeys and all herons got in together. 
29. Incia atondu o tana, incia akutua o baruna baqka o maqa hoo, kasiin po aposapolaka maqa baribaria.

30. Sabutuna o maqa ndoke aposamate baribaria atondu $i$ nuncana tawo.

31. Taqkanapo sambaa molapana.

32. O ndokemo duka mohobutina buluna panina La Hoohoo sumai molapana.

33. Atorampemo $i$ inazerna Ulouloqkobulu.

34. Sakawana apenemo $i$ ati La Ndokendoke te akahuhuhuhu.

35. Sakamatana La Ndokendoke o Uloqkobulu asapomo apentaaia, roonamo asomba beakande maliqu antona inazenna sumai.

36. Sakawana aabakimea: "I apaimo duka umina itu, Ndokendoke?"

37. Alawanimo La Ndokendoke kooni: "Kumagari. Kuminaaka $i$ Jaze".

38. Akoonimo Ulouloqkobulu: "Podo beugangauaka.

39. Aipo umina ukande antona koinazenna itu".

40. Asamaramo La Ndokendoke te akooni: "Karombuna Ulouloqkobulu ndea!

41. Ande kupapesuaia i aqoku daana amate!"

42. Alarwanimo Ulouloqkobulu: "Iqka papesua dadi!"

43. Saraqona La Ndokendoke apapesuamea $i$ nuncana aqona.

44. Laulausaka Ulouloqkobulu i otona La Ndokendoke, kasiimpo akande otona.

45. Akakeekeemo La Ndokendoke: "Mai sapo, Ulouloqkobulu! Kukaboqa!"

46. Inda araqo Ulouloqkobulu.

47. So apancuru akande otona.

48. Sampe amate o La Ndokendoke.

XIII. O sii tulatulana La Ndokendoke te La Kolokolopua.

1. Daaqia saaqu wakutuu akowao maranca.

2. Wakutuu incia sumai akomawamo o ure.

3. Apogaumo La Ndokendoke te La Kolokolopua beasapo apentaa rampe itauna mawa.

4. Akawa i uzve, asizunlumo loka sapun.

5. Lausaka aalea maqa, kasiimpo apotumpoa beapombulaia.

6. Maka o La Ndokendoke mokenina kapooli.

7. Aalamo lolona, roonamo alentua beamadeiaka akobake. 
29. When the land had disappeared, the herons pecked through the caulk of the boats, then all flew away together.

30. So all monkeys died sinking down into the sea.

31. Only one escaped.

32. The same monkey that pulled out Heron's wing-feathers was the one who escaped.

33. He was washed ashore in the garden of Hairy-Caterpillar.

34. Arrived there Monkey went on land shivering.

35. When Hairy-Caterpillar had seen Monkey, he went down to wait for him, for otherwise he would eat up everything in his garden.

36. Arrived there he asked him: "Where have you come from, Monkey?"

37. Monkey answered: "I am cold. I have come from Java".

38. Hairy-Caterpillar said: "You are propably only telling lies.

39. Perhaps you come from eating in somebody's garden".

40. Monkey became angry and said: „How bad Hairy-Caterpillar is!

41. If I put him into my nose, he is sure to die!"

42. Hairy-Caterpillar answered: "Come on, put me in, if you dare!"

43. Hearing this Monkey put him into his nose.

44. Immediately Hairy-Caterpillar went on to Monkey's brains, then he ate up his brains.

45. Monkey screamed out: "Do come down, Hairy-Caterpillar! I was joking!"

46. Hairy-Caterpillar did not listen.

47. He just went on eating his brains.

48. So Monkey died.

XIII. This is the story of Monkey and Tortoise.

1. Once upon a time it was raining very hard.

2. At the same time there was a flood.

3. Monkey and Tortoise agreed to go down to wait for flotsam carried down by the flood.

4. When they had arrived at the water, a banana tree was floating downstream.

5. Immediately they took it, then cut it in order to plant it.

6. Now Monkey was the one who held power.

7. He took the top, because he thought it would soon bear fruit. 
8. Kawa o La Kolokolopua aalamo pilita, aalamo puuna.

9. Alausaka maqa apombulaia o lokana sumai.

10. Saeona amaimo La Ndokendoke agoraaka La Kolokolopua aabakia ara pia ntakemo tareana loka ipombulana sumai.

11. Alawanino La Kolokolopua kooni: "Santakemo.

12. Ko iqkoo, Ndokendoke, pia ntakemo?"

13. "Aturen, aturen, ambaleuleu. Aturen, aturen, ambaleuleu".

14. Saeo saeo tuamo itu apogoraaka maqa, pokarvaaka amate o lokana La Ndokendoke.

15. Incia o lokana La Kolokolopua akobakemo.

16. Karea amasasamo, La Kolokolopua beakompasimea o lokana sumai.

17. Maka inda apooli.

18. Aliqkamo akemba La Ndokendoke bemokompasia.

19. Sakawana La Ndokendoke akompamo, kasiimpo apomakande. baribaria loka masasa sumai.

20. Agoramo La Kolokolopua: "Taburakaakaakupo sagaa te iaku, Ndokendoke!"

21. Maka o La Ndokendoke inda ataburakaakea.

22. So ataburaka kulina, o antona apadea akandea.

23. So alazeani: "Bolipo iqkoo. Kupenapenamiqkukupea".

24. Pokareaaka amapupu o bakena loka sumai.

25. Sabutuna La Kolokolopua kakeakeamo incana.

26. Aliqkamo atadami ampa, kasiimpo atumbulakea i saripina punna loka sumai ataaia $i$ korumpuana.

27. Kasiimpo apaumba La Ndokendoke kooni:

28. "Ande usabu, Ndokendoke, boli usabu $i$ madetedetena, sabu $i$ marumpurumpuna!

29. Roonamo ande usabu $i$ madetedetena beaworako mantoana lakina lipu".

30. Samapupuna o loka masasa sumai akandea La Ndokendoke asabumo $i$ weta marumpurumpuna, lausaka akana i ampa itaana La Kolokolopua.

31. Sampe amate La Ndokendoke.

32. Sakamatana incia sumai La Kolokolopua aalamo mbalo, kasiimpo ataanakaaka raana La Ndokendoke, kasiimpo aliqka aaso.

33. Tee baquna gorana kooni: "Inda uali, inda uali o gola, yeye?!" 
8. When Tortoise made his choice, he took the trunk.

9. They proceeded to plant their bananas.

10. Next day Monkey came calling Tortoise asking him, how many leaves the banana had he had planted.

11. Tortoise answered: "One leaf.

12. And you, Monkey, how many leaves?"

13. "It is growing a little, it is drooping a little. It is growing a little, it is drooping a little!"

14. Each day they called out to each other like this, until Monkey's banana died.

15. Tortoise's banana however bore fruit.

16. When it was ripe, Tortoise wanted to climb into his banana tree.

17. But he could not.

18. He went to call Monkey who was to climb into it.

19. Arrived there Monkey climbed, then he ate all the ripe bananas.

20. Tortoise called: "Drop some for me also, Monkey!"

21. But Monkey did not drop any for him.

22. He only dropped the skins, the contents he ate up.

23. He only answered: "Wait a moment, you! I shall eat them up little-by-little".

24. So it went on until the fruits of this banana were finished.

25. So Tortoise fell into a rage.

26. He went to sharpen man-traps, then he set them in the ground beside the banana tree setting them in the grassy plot.

27. Then he said to Monkey:

28. "When you jump down, Monkey, do not jump down on to the plain, jump down on to the grassy plot.

29. For if you jump down on to the plain, you will be barked at by the ruler's dogs".

30. After Monkey had eaten up all the ripe bananas, he jumped down on the grassy side and immediately came down on to the mantraps set up by Tortoise.

31. So Monkey died.

32. Seeing this Tortoise took a bamboo, then he collected Monkey's blood in it, then he went to sell it.

33. And the way he called was: "Oh, won't you buy, won't you buy sugar?!" 
34. Saraqona o lakina lipu atumpumo mia bemogoraaka La Kolokolopua beaali golana sumai.

35. Sapadana aalia kawa beapomea haragaana, La Kolokolopua amendeu aala kupa, tabeana beaala mbololo.

36. Aalamo mbololo o haragaana gola sumai.

37. Incia satotuuna mincuana gola, tabeana o raana La Ndokendoke.

38. Sakaaratea dala La Kolokolopua aliqkaaka rambi o mbololona sumai temo alagu:

39. "Atidoqu, atidoqu, atidololololo!

40. Ukandekande o bukuna raqamiu. Usumpusumpu o raana raqamiu".

41. Saraqona lakina lipu asamaramo.

42. Atumpu mia bemogoraakea La Kolokolopua.

43. "Aipo La Kolokolopua sii amaqapaalimo raa.

44. Aipo mincuana gola".

45. Saraqona kakemba La Kolokolopua amaimo.

46. Kar'a aabakia, amaqakumo kooni:

47. "Mincuana gola, o raa!"

48. Ahukumumea La Kolokolopua beasumbelea.

49. Aundamo La Kolokolopua beatosumbele, maka tabeana beapopolaqo $i$ paana lakina lipu.

50. Apopolaqomo i paana lakina lipu.

51. Incia adodoa o borokona, incia asozwo o baana La Kolokolopua.

52. Sabutuna o kapulu kasumbelena sumai akanamo paana lakina lipu.

53. Lausaka amate o lakina lipu.

54. Taqkanapo.

XIV. Tulatulana La Paapaando.

1. Saeoakana akambelimbelimo La Paapaando i nuncana koo.

2. Daaqia akana incana, roonamo pada agau harimau.

3. So aliqkaakamo akaketekete.

4. Sadia daaqia audani o hariman igauna $i$ saao.

5. Maka sanampun araqomo ruqka.

6. Apoilimo i talikuna.

7. Akamatamo o harimau igauna i saao itu.

8. Opeamo ikarajaa? Taqkanamo o palai.

9. Sanampuu abuntulimo.

10. Inda amataua $i$ apai apalai, so aliqkamo.

11. Maka o harimau humai akamata La Paapaando humai apalai, abuntubuntulimo uka i talikuna. 
34. Having heard this the ruler commanded someone to call to Tortoise that he would buy his sugar.

35. Having bought it he wanted to pay the price, but Tortoise did not want to take money, but he wanted to get a gong.

36. He got a gong as price for that sugar.

37. But actually it was not sugar, but Monkey's blood.

38. All the way Tortoise went beating his gong and singing:

39. "Bang-bong, jingle-jangle!

40. You are eating the bones of your comrade, you are drinking your comrade's blood".

41. Hearing this the ruler got angry.

42. He commanded someone to call for Tortoise.

43. "Maybe Tortoise has sold us blood.

44. Maybe it is no sugar".

45. Hearing the calling Tortoise came.

46. When asked, he admitted saying:

47. "It is no sugar, it is blood!"

48. He condemned Tortoise to be slaughtered by him.

49. Tortoise agreed to be slaughtered, but he should have the ruler's thigh as a cushion.

50. He indeed did get the ruler's thigh as a cushion.

51. The very moment that he was going to cut off his neck, Tortoise drew in his head.

52. So the slaughter-knife hit the ruler's thigh.

53. Immediately the ruler died.

54. That is all.

XIV. A story of Mouse-deer.

1. One day Mouse-deer was walking in the wood.

2. He was pleased, because he had tricked the tiger.

3. He walked along sniggering.

4. All the time he remembered the tiger he had just tricked.

5. But suddenly he heard a rustling.

6. He looked back.

7. He saw the tiger he had just tricked.

8. What should he do? Only flight.

9. Suddenly he ran away.

10. He did not know where he was running, he just ran.

11. But the tiger saw Mouse-deer running away and trotted after him. 
12. Atumpumo incana akamata La Paapaando humai indamo amatau incana apalai.

13. La Paapaando adarendazen mpun incana abuntuli.

14. Sanampun akareamo umala maoge.

15. Opeamo ikarajaa?

16. Apotonto i talikuna, daaqia te harimau.

17. Apotonto $i$ aroa, daaqia te ure.

18. Asukaramo mpuu incana.

19. O harimau humai akatootooromo uka akamakamata La Paapaando inda momatauna incana humai.

20. Atumpumo mpuu incana te akooni i incana: "Siisii kupoolikomo!"

21. Maka sanampuu La Paapaando akamatamo buea mopoqano.

22. Agoraakamea: "He sabaqka! I apai ulipa itu?

23. I apai maqa sabaqkamin, ka inda kukamatea?

24. Buaka inda uraqo?"

25. "Taraqo opea?"

26. "O lakina lipu sii apeelu beamatana kabarimiu.

27. Mbakanamo iqkomiu harusu utogagari.

28. Sipea, daaqiamo te harimau mokamakamatana uka kabarimiu.

29. Mbakanamo pokembakembamo, mamudaakana utogagariaka siisii",

30. O buea humai akembamo maqa sabaqkana.

31. Aposaumbaumbamo uka reakutuu incia humai.

32. "Potalatala adi komiu, mamudaakana amalape kugagarikomiu".

33. Maqa buea humai aporapirapimo.

34. Abukea o kaezana umala humai rampana kabarina.

35. La Paapaando atumpumo incana.

36. Apepuumo agagari: "sambaa, rua mbaa....", sampe apadea.

37. Maka akareamo uka $i$ sazvetana umala, roonamo apolandamo $i$ torukuna maqa buea humai.

38. "O sii padamo utogagari komiu.

39. Mbulimo i banuamiu!"

40. O harimau rampana katumpuna incana $i$ saao o La Paapaando amarasaimo indamo aparahatikaia opeamo ikarajaana La Paapaando.

41. Incia mpun akamatea garaaka o La Paapaando $i$ sawetanamo o umala, alumbumo mpun o incana.

42. Apajeremea abuntulimo.

43. Maka kawa i taqataqana uwe so atidomu. 
12. He was glad to see that Mouse-deer was upset while he ran.

13. Mouse-deer greatly concentrated on running.

14. Suddenly he reached a great river.

15. What should he do?

16. He looked around, there was the tiger.

17. He looked in front, there was the water.

18. He was in a pinch.

19. The tiger sat down looking at Mouse-deer who did not know what to do.

20. He was very pleased and said to himself : "Now I have got you!"

21. But suddenly Mouse-deer saw a crocodile swimming.

22. He called to him: "Say comrade! Where are you going?

23. Where are your comrades, for I don't see them?

24. Haven't you heard?"

25. "What should we have heard?"

26. "The ruler wants to know your number.

27. So you must be counted.

28. Look here, the tiger also sits looking at your number.

29. So call each other, that you may now be counted".

30. The crocodile called his comrades.

31. They all came at the very moment.

32. "You go and lie next to each other in order that I can count you well".

33. The crocodiles lay down side by side.

34. The breadth of the river was filled by their number.

35. Mouse-deer was glad.

36. He began counting: one, two.... until he was ready.

37. But he had also reached the other side of the river, as he had walked over the backs of the crocodiles.

38. "Now you have been counted.

39. Go back home!"

40. The tiger had taken no notice of what Mouse-deer was doing because of his joy that Mouse-deer was in difficulties.

41. As soon as he saw that Mouse-deer was actually at the other side of the river, he got very angry.

42. He followed him running.

43. But halfway the water he sank down. 
44. Rampana o lumbuna $i$ saao inda amataua garaaka ilandakina sii o maqa buea asaroqia podo batana kau.

45. Atidomupo, kasiimpo amatau incana.

46. Garaaka apapenaminea uka o La Paapaando.

47. Sataqa mate, kasiimpo akawa $i$ ati.

48. Maka o La Paapaando indamo atokamata i apai alipa.

XV. O sii tulatulana Wa Ndiudiu.

1. Baabaana o mia sumai te anana rua mia samia bawine, samia umane.

2. O bawine o sarona $W a$ Turuqkoleo.

3. O umane o sarona La Mbatambata.

4. Kawa o amana Wa Turuqkoleo te La Mbatanbata sumai ataamo kampepe.

5. Akanamo ikane kampepena sumai.

6. Aalamea, kasiimpo awolea, ka adikaia $i$ ombu.

7. Kawa aliqka o amana Wa Turuqkoleo, ajanjinno inana Wa Turuqkoleo, mamudaakana boli alea o kawolena sumai.

8. Akoonimo inana. Wa Turuqkoleo:

9. "Incemamo beaalea, taqkanamo maqa anaana sii".

10. Alawanimo amana $W a$ Turuqkoleo:

11. "Moomini maqa anaana sii boli alaakea".

12. Inda maqeqe aliqka, ataqimo La Mbatambata gauna beakandc kawolena amana sumai.

13. Adaremea ikane o inana, maka amendeu so ataqi arambirambitaka karona, tabeana beakande kawolena amana.

14. Akamata incia sumai, o inana amaasimo adodoakamea lencilencina saide, ka atunuakea.

15. Daaqiamo i nuncana akandekandea, akawamo amana.

16. Sakamatana lausaka alipa aparakisaa kawolena.

17. Incia akamatea akailaqamo, incia asamaramo.

18. Akoonimo inana La Mbatambata:

19. "Tombakana so kualaakamo, roonamo amendeu akande ikane, tabeana o kawolemu, kualaakamea lencina saide, roonamo arambirambitakamo karona".

20. So alawani amana: "Moomini ataqi, boli alaakea".

21. Temo aala parewana tanuana inana La Mbatambata, kasiimpo abebcaka inana La Mbatambata, sampe amakatukatu. 
44. Through his anger he did not know that really what he stepped on were crocodiles. He thought it was only stems.

45. Only while he was sinking, he came to himself.

46. Truly, Mouse-deer had tricked him again.

47. He was half dead before he came on land.

48. But is was no longer to be seen where Mouse-deer had gone.

\section{This is the story of Wa Ndiudiu.}

1. Once upon time there were people who had two children, one a boy and one a girl.

2. The name of the girl was Wa Turuqkoleo.

3. The boy was called La Mbatambata.

4. It came to pass that Wa Turuqkoleo and La Mbatambata's father put out bow-nets.

5. Fish came into these bow-nets.

6. He took them, then cleaned them, then he put them in the smoke.

7. While Turuqkoleo's father went away, he impressed Wa Turuqkoleo's mother not to take the cleaned fish.

8. Wa Turuqkoleo's mother said:

9. "Who would take it, only these children".

10. Wa Turuqkoleo's father answered:

11. "Even for these children you must not take them".

12. He had not been gone long, when La Mbatambata began to cry saying that he wished to eat his father's cleaned fish.

13. His mother gave him fish, but he refused. He just cried, beating about his body, but he wanted to eat his feather's cleaned fish.

14. Seeing this his mother felt pity for him. She cut off a piece of tail for him, then roasted it for him.

15. While he was eating it up, his father came.

16. As soon as he saw it, he immediately went to investigate his cleaned fish.

17. As soon as he noticed some of it was gone, he got angry.

18. La Mbatambata's mother said:

19. "The reason I took it for him is that he refused to eat fish, but only wanted your cleaned fish; I took a piece of tail for him, as he was beating about his body".

20. His father only answered: "Even if he cries, you must not give it to him".

21. And he took the weaving-loom of La Mbatambata's mother, then he hit La Mbatambata's mother with it till it broke. 
22. So asarandarandamo, so asambelambelamo inana La Mbatambata.

23. Sapadana tua sumai incia aonto asikisaaia, incia akemba La Mbatambata apasusua.

24. O Wa Turuqkoleo akembaia $i$ saripina temo ataqitaqisia te apaumbaia:

25. "Ande inda ukandea ntaupo o kawolena amamu inda bekuponamisi tua sii".

26. Temo duka apaumba Wa Turuqkoleo:

27. "So umboombooremo itu komiu maasiakea o andimu, roonamo iaku bekuliqkamo, karana o amamiu alabi kawolena te iqkomin".

28. Satumpuna incana o La Mbatambata asusu aalamo biana o inana te bajuna, kasiimpo aposaqa $i$ anana ruamiaia, kasiimpo aliqka.

29. Sakawana $i$ lawalawana banuana abencibencimo biana, kasiimpo ataburakea $i$ dala sakaaratea dala, mamudaakana beakamatea anana.

30. Amapupu biana, abencibencimo bajuna.

31. Incia aтарири o bajuna, incia akawa $i$ tawo.

32. Aaronimo ajimana, kasiimpo adikaia $i$ bawona batu, kasiimpo ataburaka karona $i$ tawo.

33. Karea amalo, La Mbatambata samaloa ataqiaka inana, amatuumo borokona.

34. So akooni o amana apaumba Wa Turuqkoleo: "Pasumpuakea uwe!"

35. So abukemo kompona, inda aonto ataqi.

36. Saeona malomalo atambimea $W a$ Turuqkoleo o La Mbatambata, aliqkamo apeelo inana.

37. Salimbana $i$ lawalawana banuana akamatamo kabencina biana inana.

38. Ataqimo temo akooni:

39. "Garaaka ndea, Mbatambata, o inata sii abencibencimea o biana, madaakana iqkoo $i$ ari umempili ukande.

40. Ande inda ukande kawolena amata ntaupo inda bealiqka o inata, sadaadaa tamboomboore te inata.

41. Maka iqkoo umempili.

42. Incia o amata alabiaka kawolena te iqkita".

43. Anunumo kabencina biana inana sumai maqa temo aliqkaaka taqi sakaaratea dala. 
22. La Mbatambata's mother was all covered with bruises and wounds.

23. When that was finished, as soon as he stopped punishing her, she called La Mbatambata and suckled him.

24. She called Wa Turuqkoleo to her side, while she kept weeping over them, and said:

25. "If you had not eaten your father's cleaned fish, I would not suffer like this".

26. She also said to Wa Turuqkoleo:

27. "You just stay here, be kind to your brother, for I am going away, because your father esteems his cleaned fish more that you".

28. When La Mbatambata was satisfied with sucking, his mother took her sarong and her jacket, then she said farewell to both her children, then she went away.

29. Arrived at the gate of the house she tore up her sarong, then threw it on the road all along the road, in order that her children should see it.

30. When her sarong was used up, she tore up her jacket.

31. Just when her jacket was used up, she arrived by the sea.

32. She loosened her amulet, then laid it on a stone, then she threw herself into the sea.

33. At night La Mbatambata cried all the night for his mother, his throat being dry.

34. His father only said to Wa Turuqkoleo: "Let him drink water".

35. Although his stomach was full, he did not stop crying.

36. Next morning Wa Turuqkoleo carried La Mbatambata and went to look for her mother.

37. As she went out by the gate of her house, she saw the torn pieces of her mother's sarong.

38. She wept and said :

39. "Truly, Mbatambata, there our mother has torn her sarong, because you were so fastidious in eating yesterday.

40. If you had not eaten of our father's cleaned fish, our mother would not have gone away, we would still be with our mother.

41. But you were fastidious.

42. Our father esteems his cleaned fish more than us".

43. They looked for the torn pieces of their mother's sarong and went weeping along the whole road. 
44. O Wa Turuqkoleo aliqkaaka lagu te ataqi.

45. Tee baquna laguna:

46. "Wa ina, Wa Ndiudiu, mai pasusu andiku.

47. Andiku La Mbatambata, iaku Wa Turuqkoleo".

48. Samaqeqena akaliqkaliqka akamatamo duka kabencina bajuna.

49. Akoonimo duka o Wa Turuqkoleo apaumba La Mbatambata:

50. "Garaaka ndea o inata sii atalanjamo indamo te pakeana.

51. O bajuna abencibencimea duka".

52. Pokarwaka akarea $i$ tawo.

53. Sakawana $i$ tawo akamatamo ajimana inana $i$ barvona batu.

54. Aalamea topoudaniana te inana.

55. Wakutuu incia sumai daaqia te maqa mopebuanina.

56. Aabakimo mopebuanina sumai:

57. "Inda ukamata iqkomiu o bawine aliqkaaka taqi $i$ arei?"

58. Alawanimo mopebuanina sumai:

59. "Takamata $i$ arei, maka aleamo $i$ nuncana tawo sii, indamo abaqu pokawaaka malo".

60. Ataqimo Wa Turuqkoleo te La Mbatambata.

61. Temo duka alagu o Wa Turuqkoleo simbao duka laguna $i$ saao.

62. Saliqkana mopebuanina sumai abaqumo inana $W a$ Turuqkoleo minaaka incana tawo te katarena ikanena.

63. Maka akoonamo o bawona aena simbao ikane.

64. Sakawana asaqomo La Mbatambata, kasiimpo apasusua.

65. Temo duka ataqitaqisia te apaumbaia:

66. "Ande so ukande ntaupomo inda betapogaa te iaku".

67. Incia atumpu incana La Mbatambata asusu, atumpumea ambuli $i$ banuana te Wa Turuqkoleo te adazenakamea katarena ikanena sumai.

68. Wa Turuqkoleo te La Mbatambata beaosemo inana, maka amendena te akooni:

69. "Bolimo ose iaku!

70. Boliakamo iqkomiu mbulimo i banua, roonamo iaku sii bekumembalimo ikane.

71. Coba kamatea sii!

72. O bawona aeku sii apepuumo akoona".

73. Ambulimo Wa Turuqkoleo te La Mbatambata $i$ banuana akenikenimo te katarena ikanena.

74. Apaumbamea duka o inana sumai: 
44. Wa Turuqkoleo went singing and weeping.

45. And what she sang was:

46. "Mother Wa Ndiudiu, come, suckle my brother.

47. My brother is La Mbatambata, I am Wa Turuqkoleo".

48. When they had been walking for a long time, they also saw pieces of her jacket.

49. Wa Turuqkoleo again said to La Mbatambata:

50. "There, our mother was naked, she had no more cloths on.

51. Her jacket she also tore up".

52. Then they came by the sea.

53. Arrived by the sea they saw their mother's amulet on a stone.

54. They took it with them as a souvenir of their mother.

55. At the same time fishermen were there.

56. They asked these fishermen:

57. "Did not you yesterday see a woman who walked along weeping?"

58. The fishermen answered:

59. "We did see yesterday, but she dived into the sea; she had not come up when evening came".

60. Wa Turuqkoleo and La Mbatambata wept.

61. And Wa Turuqkoleo again sang the same she had just sung.

62. When the fishermen had gone away, Wa Turuqkoleo's mother emerged from the sea with a bunch of fish.

63. But the upper side of her feet had scales like a fish.

64. When she had come, she took La Mbatambata on to her lap, then suckled him.

65. She also wept over him and said to him:

66. "If you had just eaten, then you would not part from me".

67. As soon as La Mbatambata was satisfied with sucking, she sent him back home with Wa Turuqkoleo and gave them that bunch of fish.

68. Wa Turuqkoleo and $\mathrm{La}$ Mbatambata wanted to follow their mother, but she refused saying:

69. "Do not follow me!

70. You gust go home, for I shall become a fish.

71. Just look at this!

72. The top of my feet has already begun to grow scaly".

73. Wa Turuqkoleo and La Mbatambata returned home carrying their bunch of fish with them.

74. Their mother also said to them: 
75. "Ande aabakikomiu amamiu itu paumbaia inda upokawa te iaku te o ikanemiu itu adazerkomiu mia momaasina".

76. Sapadana aleamo duka $i$ tawo o inana sumai.

77. Sakawana $i$ banua aabakimea amana:

78. "Upokawa te inamiu?"

79. Alawanimo maqa: "Inda tapokawa".

80. "Ko ikanemiu itu $i$ apai uala?"

81. "Adarenkami momaasina $i$ tawo siroo".

82. Lausakamo aalea amana o ikane sumai, kasiimpo anasua, ka akande.

83. O Wa Turuqkoleo te La Mbatambata so adawu saide.

84. Kawa amalo, samaloa duka o La Mbatambata ataqiaka inana te amatuu borokona.

85. Saeona atambimea duka Wa Turuqkoleo o La Mbatambata, ka asapo i tawo, ka alagu duka:

86. "Wa ina, Wa Ndiudiu, mai pasusu andiku!

87. Andiku La Mbatambata, iaku Wa Turuqkoleo".

88. Saraqona duka kaasi o inana abaqumo duka temo duka katarena ikanena.

89. Sakawana apasusumo duka La Mbatambata.

90. Satumpuna duka incana asusu ambulimo duka maqa $i$ banuana.

91. O inana aleamo duka $i$ tawo.

92. Saeo saeo tuamo itu, pokawaaka pitu eo.

93. Incia akawa pitu eo, incia atipumo onana.

94. Somo susuna indapo mokoonana.

95. Wakutuumo incia sumai akoonimo Wa Ndiudiu kooni:

96. "Naile komiu bolimo sapo, roonamo iaku indamo amembali bekupene $i$ ati.

97. Tombakanamo komiu boliakamo, akonowiapo, kasiimpo umbuli $i$ banua, roonamo eomo sii kapadaana tapokaze".

98. Incia akonowia, atumpumo incana La Mbatambata asusu.

99. Ambulimo maqa temo duka katarena ikanena.

100. Asamaramo amana, roonamo analo, kasiimpo ambuli sumai.

101. Saeona asapomo duka $i$ tawo Wa Turuqkoleo te La Mbatambata.

102. So amaqulemo alagu o Wa Turuqkoleo, indamo abaqu o inana, pokawaaka asoo eo.

103. Taqkanamo so akamatamo katarena ikane $i$ bawona batu diqkanana ajimana inana sumai.

104. So aalamo katarena ikane sumai maqa, kasiimpo ambuli. 
75. "When your father asks you, tell him that you did not meet me and that someone who felt pity gave you this fish".

76. Then their mother dived into the sea again.

77. When they came home their father asked:

78. "Did you meet your mother?"

79. They answered: "We did not meet her".

80. "And these fish of yours, where did you get them?"

81. "A kindhearted person gave them to us there by the seaside".

82. At once their father took the fish, then he cooked them and then ate them up.

83. To Wa Turuqkoleo and $\mathrm{La}$ Mbatambata he only gave a little bit.

84. When night had fallen, La Mbatambata cried again the whole night for his mother and his throat was dry.

85. Next day Wa Turuqkoleo again took along La Mbatambata in a cloth and went to the sea; then again she sang:

86. "Mother Wa Ndiudiu, come, suckle my brother.

87. My brother is La Mbatambata, I am Wa Turuqkoleo".

88. When she heard this again, sad to relate!, their mother again emerged and again she had a bunch of fish with her.

89. When she had come, she again suckled La Mbatambata.

90. When he was satisfied again with sucking, they returned home again. 91. Their mother dived back into the sea.

92. It was the same thing each day, until seven days had passed.

93. When the seventh day had come, she was quite scaly.

94. Only her breasts were not yet scaly.

95. At that moment $\mathrm{Wa}$ Ndiudiu said:

96. "Tomorrow you must not come, for I will no longer be able to come on land.

97. For that reason you should just stay until midday, then go home, for this will be the last day that we meet each other".

98. At midday La Mbatambata was satisfied with sucking.

99. They went back home with their bunch of fish.

100. Their father was angry, because it was evening by the time they returned. 101. Next day Wa Turuqkoleo and La Mbatambata again went to the sea.

102. Although Wa Turuqkoleo tired herself out with singing, her mother did not come up, until the sun set.

103. They only saw a bunch of fish on the stone on which the amulet of their mother had been laid.

104. They only took that bunch of fish, then they went home. 


\begin{abstract}
ADDITIONS
Page 15

Deviant, both in form and in derivation, is koamasina — to be demanding, ambitious, from masina - jealous, desirous.
\end{abstract}

Page 18

Irregular is the form of kapeepewuli - to tell lies.

\title{
Page 18**
}

Productivity occurs in the case of denominal pe-verbs meaning either "fish with" or "play with":

peompo - catch fish with a trap, ompo - fish trap.

pepuka - to fish with a dragnet, puka - dragnet.

pebuia - to play cards, buia - playing card.

pegolu - to play with a ball, golu — ball.

\section{Page 19}

Members of this category - which is productive - show a tendency to distinguish between a dual actor form with unreduplicated root and a plural actor form with reduplicated root.

pogaa - part, separate (of two persons), pogaagaa - disperse, split up (of many people, a meeting), gaa - part, go away.

This reciprocal form may be based on another $p o$ - form:

popotawai - smile at each other, potawa - to smile.

\section{Page 21}

The same double suffix as in potawaiki is found in samaraiki - to be angry with, from samara - to be angry.

\section{Page 22}

Exceptional is jamasaaka - to attend the Friday service in the mosque, from jamasa - Friday service. 


\section{Page 27}

$h$. Suffix $-a$. This suffix gives the verb-form a subjunctive meaning. matana ingkoo - that you may know!

\section{Page 29}

More or less in between these two types are formations like tohobuti - fall out (of hair or feathers), hobuti - pull out. toloe - hang, loe - hang up. topinto - fall off, pinto - emerge.

Exceptional is the case of tomeriaka - doubt (transitive!) from meri - be in doubt.

\section{Page 29**}

The stems in question may well be regarded as a subclass of the verb and called adjectives. These further show the possibility of a formation with prefix sa- and suffix -na. The meaning of these is: having a high degree of...

samalapena - as beautiful as can be, from malape - beautiful.

\section{Page 31}

If derived from a noun, the meaning usually is: thing shaped like, imitation of:

kapisopiso - kind of fish, having the shape of a knife, from piso knife.

karourou - picture of a face, from rou - face.

In cases like these there is a variant form with $q k a$-.

Page 32

Prenasalization of the initial consonant of the root is found in:

kampalea - obstacle, from pale - to pass.

\section{Page 33}

Combination with suffix $-i$ is found in:

kalelei - habit, custom, from lele - permanent.

Page 33**

XV. Prefix maqa-. This non-productive prefix forms agent-nouns from verbs:

$$
\begin{aligned}
& \text { maqaagoi - robber, from agoi - to rob. } \\
& \text { maqapoqko - murderer, from poqko - to kill. }
\end{aligned}
$$




\section{Page 34}

$f$. Also found with numeral coefficients only is the prefix ko-, with the meaning "some, a few":

kombula - some months.

kotao - a few years. 


\section{BIBLIOGRAPHY}

Abas, Husen, A. Kadir Manyambeang, Ibnu Nandar and Shaidy

1983 Struktur Bahasa Wolio. Jakarta: Pusat Pembinaan dan Pengembangan Bahasa, Departemen Pendidikan dan Kebudayaan, xiii + 62 pp.

Abas, Husen, Shaidy and Lukmanulhakim Jaya

1985 Kamus Wolio-Indonesia. Jakarta: Pusat Pembinaan dan Pengembangan Bahasa, Departemen Pendidikan dan Kebudayaan, xiv + 191 pp.

Abidin, Salmayati

1983 Proses morfemis kata kerja Bahasa Wolio. Ujung Pandang: Fakultas Ilmu-Ilmu Sosial dan Budaya, Universitas Hasanuddin, viii + 99 pp. [M. A. thesis.]

Anceaux, J. C.

1952 The Wolio language; Outline of grammatical description and texts. 's-Gravenhage: Nijhoff, iv + 93 pp. [KITLV, Verhandelingen 11.]

1978 'The linguistic position of South-East Sulawesi: a preliminary outline', in: S.A. Wurm and Lois Carrington (eds), Second International Conference on Austronesian Linguistics: Proceedings, I. Western Austronesian, pp. 275-283. Canberra: Department of Linguistics, Research School of Pacific Studies, Australian National University. [Pacific Linguistics, Series C, No. 61.]

1981 'Regelmaat en produktiviteit in een Austronesische taal', Forum der Letteren .22:143-147.

1986 'Sociale en taalkundige aspecten van de Wolio letterkunde', in: C. M. S. Hellwig and S. O. Robson (eds), A man of Indonesian letters; Essays in honour of Professor A. Teeuw, pp. 238-241. Dordrecht/ Cinnaminson: Foris. [KITLV, Verhandelingen 121.]

1987 Wolio dictionary (Wolio-English-Indonesian) - Kamus Bahasa Wolio (Wolio-Inggeris-Indonesian). Dordrecht/Providence: Foris, xix + 195 pp. [KITLV.]

Berg, E. J. van den

1937 'De viering van den raraja hadji in de Kota Wolio (Boeton)' Tijdschrift voor Indische Taal-, Land-en Volkenkunde (TBG) 77:650660 . 
1939 'Adatgebruiken in verband met de sultansinstallatie in Boeton', Tijdschrift voor Indische Taal-, Land-en Volkenkunde (TBG) 79:469528.

1939 'Poelau Makassar', Cultureel Indië 1:366.

Cense, A. A.

1954 'Mededelingen uit de verslagen van Dr E. J. van den Berg', Bijdragen tot de Taal, Land-en Volkenkunde 110:154-184.

Gani, Ambo, H. Abd. Kadir Manyambeang, Ibnu Nandar, Hamzah Mahmud and Lukmanul Hakim

1986 Morfologi kata kerja Bahasa Wolio. Jakarta: Pusat Pembinaan dan Pengembangan Bahasa, Departemen Pendidikan dan Kebudayaan, $\mathrm{xv}+70 \mathrm{pp}$.

Malim, La Ode

1981 Kesenian daerah Wolio. Jakarta: Proyek Penerbitan Buku Sastra Indonesia dan Daerah, Departemen Pendidikan dan Kebudayaan, $52 \mathrm{pp}$.

Mattalitti, M. Arief, Muhammad Sikki, Amir Kadir, Shaidy and Abd. Kadir Mulya

1985 Sastra lisan Wolio. Jakarta: Pusat Pembinaan dan Pengembangan Bahasa, Departemen Pendidikan dan Kebudayaan, xiii + 85 pp.

Zahari, Abdul Mulku

1979 Sekelumit bahasa daerah Wolio. Baadia, xi + 412 pp. [Typescript.]

1981 Adat dan upacara perkawinan Wolio. Jakarta: Proyek Penerbitan Buku Sastra Indonesia dan Daerah, Departemen Pendidikan dan Kebudayaan, 148 pp. 